\title{
Microphysical structures associated with enhancement of convective cells over Mt. Halla, Jeju Island, Korea on 6 July 2007
}

\author{
Keun-Ok LEE ${ }^{1 \dagger}$, Hiroshi UYEDA ${ }^{1}$, and Dong-In LEE ${ }^{2}$ \\ 1) Hydrospheric Atmospheric Research Center, Nagoya University, Japan \\ 2) Dept. of Environmental Atmospheric Sciences, Pukyong National University, Korea
}

\begin{abstract}
An intense precipitation system that developed during the rainy season generated an enhanced rainfall event over the northern and lee sides of an isolated elliptical-shaped area (Mt. Halla: height $1950 \mathrm{~m}$, width $35 \mathrm{~km}$, length $78 \mathrm{~km}$ ) of Jeju Island on 6 July 2007. In this study, we investigate the microphysical structures associated with the developed convective cells interior of the system, which was shown in the vicinities of a terrain, using a cloud-resolving storm simulator (CReSS) that successfully reproduced the intensification of the convective cells. A control experiment simulated the terrain-modified go-around airflow (i.e., the flow of air around Mt. Halla rather than over it) and two localized moist regions (relative humidity $>96 \%$ ) on the northwestern side and southeastern slope of the island. Regarding the intensification of the convective cell off the northwestern shore of the island, an increase in updraft was seen from the sea surface to an altitude of $1.5 \mathrm{~km}$ (maximum at $4.5 \mathrm{~km}$ ), where the moisture content was high $\left(17 \mathrm{~g} \mathrm{~kg}^{-1}\right)$. Due to the increased updraft and plentiful moisture supply at low altitudes, cloud water increased from the sea surface to reach a maximum at an altitude of $2.7 \mathrm{~km}$. Consequently, the microphysical processes that convert cloud water into raindrops (e.g., collection and conversion) were significant below $4.3 \mathrm{~km}$, and an increase in rainfall was seen between heights of 1.0 and 4.2 $\mathrm{km}$; i.e., mainly below the freezing level $(4.9 \mathrm{~km})$. With regard to the enhancement of the convective cell on the lee side of the island, an increase in updraft was seen above $1 \mathrm{~km}$ (maximum at $5.5 \mathrm{~km}$ ). The plentiful moisture supply, which was localized on the southeastern slope of the island, was supplied to the convective cell by the southwesterly upslope wind at low altitudes. Driven by the moist updraft above $1.0 \mathrm{~km}$, cloud water increased above $1.5 \mathrm{~km}$, and the microphysical processes that produce raindrops were significantly activated in the region between 1.5 and $5.3 \mathrm{~km}$ in altitude, which extended above the freezing level. Consequently, above the freezing level, the melting rate of graupel decreased while cloud water increased during the intensification of convective cell on the lee side. Off the northwestern shore of the island, most of the hydrometeors increased significantly from the sea surface to below the freezing level as a result of the warm rain process. In contrast, on the lee side, the hydrometeors increased below and above the freezing level due to the action of both stationary terraingenerated convergence, and the southwesterly upslope wind in a moist environment; consequently, both of the active warm and cold rain processes contributed to the generation of the secondary enhancement.
\end{abstract}

Keywords: Microphysical structure, Orographically-enhanced rainfall, Moist environment

\section{Introduction}

One of the most significant challenges associated with the prediction of rainfall over regions adjacent to mountain ranges is properly assessing the impact of orography on precipitation distribution and intensity (Smith 1979; Lin 2007). In an attempt to develop a better understanding of the mechanisms that control orographically

\footnotetext{
$\dagger$ Corresponding author at: Hydrospheric Atmospheric Research Center, Nagoya University, Furo-cho, Chikusa-ku, Nagoya, 4648601, Japan. Tel.: +81 527893492; fax: +81 527893436. E-mail address: leeko@rain.hyarc.nagoya-u.ac.jp
} 
induced precipitation systems, previous studies have examined factors such as low-level convergence, wind blocking (measured by the Froude number, Fr), ambient wind direction and speed, steepness of the topography, and latent heating and cooling processes induced by various terrain morphologies (Smolarkeiwicz and Rotunno, 1989; Li et al., 1997; Chiao and Lin, 2003; Jiang, 2003; Petersen et al., 2003; Reeves and Lin, 2007; Xu et al., 2012). Many theoretical studies have investigated the interaction between dry atmospheric flows and topography by numerical experiments, showing the critical values of $F r$ which diagnose the practicable wind patterns (Miles and Huppert, 1969; Smith, 1980; Smolarkeiwicz et al., 1988; Line and Wang, 1996; Olafsson, 2000). For instance, Lin and Wang (1996) reported that the windward side of an bell-shaped obstacle is characterized by flow stagnation, with a horizontal rerouting of the low-level flow $(F r<0.6)(F r=U / N h$, where $U$ is the averaged wind speed under the height of the terrain, $h$ is the mountain height, and $N$ is the BruntVaisala frequency). Lee vortices, which are closely associated with gravity wave dynamics, form on the lee side of the mountain. In contrast, in a high- $F r$ regime $(F r>1.12)$, the strong and unblocked low-level flow is forced to ascend up the mountain slope.

When a moist airflow enters a mountainous area it is affected by orographic lifting and blocking that may modify and/or trigger cloud and precipitation systems in the vicinity. The influence of terrain on water vapor transport and precipitation has been revealed by observational, theoretical, and numerical studies (Hobbs et al., 1975; Yuter and Houze, 2003; Houze and Medina, 2005; Woods et al., 2005; Houze, 2012), which have shown that moist currents approaching and traversing mountains typically show changes in their location, strength, and intrinsic instability, resulting in significant changes in the distribution of precipitation. Furthermore, the distribution of precipitation over and near terrain of a given height and morphology is determined by a combination of the microphysics of particle growth, the dynamical behavior of a moist air mass encountering a topographic barrier, and the thermodynamics of moist air. As mountainous terrain is highly variable, and precipitation is changeable in its form and location according to the source of the moisture, these effects on precipitation processes must not be oversimplified (Houze, 2012). However, most previous studies of microphysical processes within orographically enhanced precipitation systems have focused on a large subset of the mountainous regions; it remains important to extend the domain varying of size and shape for our understanding of mechanisms underlying orographically enhanced precipitation system in a moist environment.

In East Asia, as very moist airflows prevail at low altitudes during the rainy season (June to mid-July), mountainous regions frequently experience flooding and landslides caused by orographically enhanced precipitation systems. Rowe et al. (2011) investigated the microphysical processes driving a lifting mechanism with a relatively high value of $F r$ on the southwestern upslope of Taiwan's central mountain region (CMR: height $4 \mathrm{~km}$, width $120 \mathrm{~km}$, length $320 \mathrm{~km}$ extending southwest-northeast) using polarimetric radar data. Their results indicated that the relatively strong, and very moist, southwesterly wind at low altitudes impinged on the southwestern upslope of the CMR. The interaction of this onshore flow of moist air with the mountainous terrain caused the hydrometeors to be lifted above the melting layer. Consequently, ice-based mechanisms for rainfall production became more important along the slopes of the CMR where the hydrometeors froze and grew via riming.

Fig. 1. Jeju Island: location and topography. The larger inner domain [square in (a)] was used in numerical simulations using a cloud-resolving storm simulator (CReSS) with a resolution of $1 \mathrm{~km}$. Contours show surface elevation. Smaller inner domain [square in (a)] indicates the topography of Jeju Island with a contour interval of $200 \mathrm{~m}$ [shown in (b)]. 
In moist environments such as Taiwan, orographically intensified precipitation systems have been frequently observed around Jeju Island during the rainy season (Lee et al., 2010, 2012). Jeju Island has a small, but steep, elliptical topography (height $1950 \mathrm{~m}$, width $35 \mathrm{~km}$, length $78 \mathrm{~km}$; Fig. 1b) that extends west-east. Lee et al. (2012) investigated the 3D structure of an orographically enhanced precipitation system that developed on 6 July 2007 using dual-Doppler radar analysis. As the precipitation system moved eastwards along the northern side of the island, the convective regions (radar reflectivity $\geq 45 \mathrm{dBZ}$ ) within the system was strengthened, off the northwestern shore and lee side of the island. The primary enhancement occurred off the northwestern shore of the island, in advance of its arrival onshore. As the system passed close to land, the low-level southwesterly wind strengthened between the system and the island, and this accelerated wind-related local updraft on the northwestern shore was found to be a crucial factor in the primary enhancement of the convective region. The secondary enhancement developed on the lee side of the island. A weak low-level southwesterly wind $(F r=0.2)$ blowing around the island generated local convergence on its northern lateral side and lee side. Due to this local convergence on the northern lateral side of the island, the primary enhancement of the convective region maintained its intensity. Consequently, the precipitation system reached the lee side of the island, where the convective region within the system was reinvigorated by the convergence of the go-around northwesterly wind from the northern side with the relatively strong and moist southwesterly wind from the southeastern slope. The enhancement of convective regions within the system occurred in the vicinity of terrain with a relatively small horizontal scale. However, the heights at which the convective region was significantly enhanced differed, with the primary enhancement on the northwestern shore showing strong reflectivity ( $\geq 48 \mathrm{dBZ}$ ) from the surface to an elevation of $5.5 \mathrm{~km}$ (melting layer $=4.8 \mathrm{~km}$ ), while the secondary enhancement on the lee side showed strong reflectivity ( $\geq 48 \mathrm{dBZ}$ ) up to a height of $8 \mathrm{~km}$. This result suggests that a different microphysical structure developed in the convective region during each period of enhancement. However, the limited observational data from the Doppler radar did not provide a full description of the microphysical evolution of each phase of enhancement of the precipitation system around Jeju Island.

To develop an improved understanding of the microphysical structure of the atmosphere during such enhanced precipitation events in the vicinity of Jeju Island, a cloud-resolving model with a high resolution $(<2$ $\mathrm{km}$ ) was required. In this study, a Cloud Resolving Storm Simulator (CReSS; Tsuboki and Sakakibara, 2002) successfully reproduced the enhancements of convective cells within the system that was observed on 6 July 2007. The simulation results had a resolution of $1 \mathrm{~km}$ and allowed us to investigate the microphysical structures associated with the enhancements of convective cells that occurred off the northwestern shore and lee side of the isolated elliptical-shaped terrain of Jeju Island on 6 July 2007, with a focus on the distinctive properties of the two periods.

\section{Numerical model and data analysis}

To clarify the microphysical structure of the orographically enhanced precipitation system, we performed numerical simulations using a CReSS (resolution $1 \mathrm{~km}$ ), which is a 3D non-hydrostatic model developed by the Hydrospheric Atmospheric Research Center (HyARC) of Nagoya University, Japan (Tsuboki and Sakakibara, 2002). This model employs fully compressible, non-hydrostatic dynamics, and is designed to realistically simulate mesoscale systems, at high resolution, using explicit cloud microphysics (see Table 1 for a detailed description of the model). Cartesian coordinates $(x, y)$ in the horizontal, and a terrain-following curvilinear coordinate $(\zeta)$ in the vertical directions were used, such that:

$$
\zeta(x, y, z)=z_{t}\left[z-z_{s}(x, y)\right] /\left[z_{t}-z_{s}(x, y)\right]
$$


where $z_{t}$ and $z_{s}$ are the model heights at the top and surface, respectively. With this coordinate system, the equations for 3D momentum, pressure, and potential temperature $(\theta)$ are formulated as described in detail by Tsuboki and Sakakibara (2002). The equation set includes all types of waves, such as Rossby waves, acoustic waves, and gravity waves. The final variables predicted are the 3D wind components $(u, v$, and $w)$, and the pressure and potential temperature perturbations $\left(p^{\prime}\right.$ and $\left.\theta^{\prime}\right)$ from the mean state, which is in hydrostatic equilibrium at the starting time of model integration.

Table 1. Specifications of CReSS.

The CReSS model includes a bulk cold-rain parameterization and a 1.5-order closure with a turbulent kinematic energy prediction (Tsuboki and Sakakibara, 2001). The prognostic variables in microphysics are the mixing ratios of water vapor $\left(q_{v}\right)$, cloud water $\left(q_{c}\right)$, rain $\left(q_{r}\right)$, cloud ice $\left(q_{i}\right)$, snow $\left(q_{s}\right)$, and graupel $\left(q_{g}\right)$, and the number concentrations of cloud ice $\left(N_{i}\right)$, snow $\left(N_{s}\right)$, and graupel $\left(N_{g}\right)$. The microphysical principles incorporated into CReSS are based on Lin et al. (1983), Cotton et al. (1986), Murakami (1990), Ikawa and Saito (1991), and Murakami et al. (1994). A two-moment cold-rain scheme is available in CReSS. That is, the microphysical processes of CReSS include three basic categories of processes in both the liquid water and ice phases: (1) phase nucleation, (2) growth or evaporation by diffusion, and (3) inter-particle collection.

For numerical computation in CReSS, the Arakawa C-grid staggering and the Lorenz grid are used for discretization in the horizontal and vertical, respectively. To improve computational efficiency, a mode-splitting technique (Klemp and Wilhelmson, 1987) is adopted to integrate the acoustic mode terms (and the gravity mode by option) using a smaller time step $\Delta \tau$, and the terms of all of the other modes using a larger time step $\Delta t$. The leapfrog scheme with the Asselin time filter (Asselin, 1972) is used for time stepping, while the Crank-Nicolson scheme can be used to solve $p^{\prime}$ and $w$ implicitly in the vertical for small $\Delta \tau$ by option. Computational mixing is used to remove grid-scale noise. For parallel computing, data exchange between individual processing elements was performed by the Massage Passing Interface (MPI).

We used output from the mesoscale model (MSM) developed by the Japan Meteorological Agency (JMA) for the initial and lateral boundary conditions of the numerical simulations. The JMA-MSM has a horizontal resolution of $5 \mathrm{~km}$ with $253 \times 241$ grid points and 16 vertical $\sigma$ levels. The domain of the CReSS simulation is shown in Fig. 1a (larger inner domain), and it was forward-integrated in time using the JMA-MSM output data from 2100 LST (local standard time; LST $=\mathrm{UTC}+9 \mathrm{~h}$ ) on 5 July 2007 as the initial data. In this study, ST indicates the simulation time following initial time. During the simulation, the horizontal grid size was $1 \mathrm{~km}$, and the vertical grid contained 41 levels with variable grid intervals ( $\Delta z=150 \mathrm{~m}$ near the surface and $340 \mathrm{~m}$ at the top level, at $9.5 \mathrm{~km}$ ). The horizontal domain had $850 \times 740$ grid points, with a time step of $\Delta t=3.75$ seconds

We performed two numerical simulations to investigate the influence of the terrain on Jeju Island. First, for the control simulation (CNTL), we ran CReSS with a full physical model containing topography. Second, we ran an experiment that did not incorporate the island's terrain (NOTR), in which the topography of Jeju Island was assigned an elevation of $10 \mathrm{~m}$; other conditions were the same as in the CNTL experiment.

To allow a comparison with the radar reflectivity data in Lee et al. (2012), which investigated the enhancement mechanism associated with the precipitation event on 6 July 2007 using dual-Doppler radar analysis, we estimated the reflectivity from the predicted 3D mixing ratios of rain water $\left(q_{r}\right)$, snow $\left(q_{s}\right)$, and graupel $\left(q_{g}\right)$, based on Murakami (1990). The range of the estimated reflectivity greater than $50 \mathrm{dBZ}$ is referred to as the convective cell. This range corresponds to the region of intense rainfall. 


\section{Precipitation enhancements within the 6 July 2007 system}

Fig. 2. Distributions of the simulated relative humidity (\%, grey) and mixing ratio of vapor $\left(\mathrm{g} \mathrm{kg}^{-1}\right.$, contours) at a height of $407 \mathrm{~m}$ for (a) CNTL and (b) NOTR experiments at $0020 \mathrm{ST}$.

The horizontal distributions of relative humidity $(\mathrm{RH})$ and the mixing ratio of vapor $\left(q_{v}\right)$ at 0020 ST on 6 July 2007 from the CNTL simulation are shown in Fig. 2a. The RH distribution at a height of $407 \mathrm{~m}$ indicates two moist regions (RH over 96\%) located on the northern and southeastern slopes of the island before the system approached the island. With the prevailing southwesterly wind at low altitudes, a relatively low $q_{v}$ of less than $16 \mathrm{~g} \mathrm{~kg}^{-1}$ was apparent on the northeastern side of the island. In the NOTR run (Fig. 2b), the local moist region that was found on the southeastern side of the island was hardly distributed. RH was shown to be high $(>96 \%)$ on the north of the island, and relatively low $(<88 \%)$ over the south, and $q_{v}$ increased with decreasing latitude.

Fig. 3. Rainfall amounts (mm) recorded by 17 rain gauges (dots) on Jeju Island between 0000 and 0130 LST on 6 July 2007. Rainfall amount simulated by CNTL over the whole calculation period ( 2.5 hours) is indicated by shading with thin contours of $45 \mathrm{~mm}$ and $55 \mathrm{~mm}$. The contour lines show surface elevation (interval: $200 \mathrm{~m}$ ).

The eastward-moving precipitation system passed the northern side of the island and showed two periods of enhancement of its convective cells close to the islands with mountainous terrain (Lee et al., 2012). As shown in Fig. 3, two regions of accumulated rainfall greater than $45 \mathrm{~mm}$ (deep grey shading with thin contours) were also generated by CReSS off the northwestern shore and on the northeastern side of the island. The simulated precipitation system by CReSS is compared with the rainfall distribution recorded by 17 surface rain gauges. As the rain gauges are installed on the ground surface, the comparison is restricted on the surface. On the northern coast of the island where rainfall amount of $24 \mathrm{~mm}$ in 1.5 hours recorded by rain gauge (dot), the simulated rainfall is in the range of $15-25 \mathrm{~mm}$ in 2.5 hours (the lightest grey shading). Simultaneously, on the northeastern coast of the island where the rainfall amount of $34.5 \mathrm{~mm}$ observed (dot), the simulated rainfall is in the range of 35-45 $\mathrm{mm}$. In addition, the rainfall distribution conducted by CReSS implies the enhancement of the eastwardmoving precipitation system. In the range of $33.4-33.6^{\circ} \mathrm{N}$ and $125.9-126.5^{\circ} \mathrm{E}$, the gradual increase of the accumulated rainfall amount is depicted in west-east direction; subsequently the maximum accumulated rainfall amount larger than $55 \mathrm{~mm}$ is resulted on the northern coastal region of the island $\left(33.5-33.6^{\circ} \mathrm{N}, 126.3-126.6^{\circ} \mathrm{E}\right)$. Simultaneously, in the range of $33.4-33.6^{\circ} \mathrm{N}$ and $126.7-126.9^{\circ} \mathrm{E}$, the gradual increase of the accumulated rainfall amount is characterized in west-east direction, as well as in southwest-northeast direction. With this rainfall distribution, the large amount of accumulated rainfall over $45 \mathrm{~mm}$ is shown in northeastern coast of the island.

With a good agreement with rainfall distribution of surface rain gauges and result of the radar data analysis which was conducted by Lee et al. (2012), CReSS with $1.0 \mathrm{~km}$ horizontal resolution realistically reproduced the precipitation system. The reproduced enhancements of convective cells off the northwestern and eastern sides of the island on 6 July 2007 are detailed below, and divided into two stages: the approaching stage and the lee-side stage. 


\subsection{The approaching stage}

Fig. 4. Horizontal distributions of the simulated wind (vectors) at a height of $595 \mathrm{~m}$, reflectivity (shades) at a height of 1919 $\mathrm{m}$, and convergence (symbols), simulated by the CNTL experiment for (a) $0030 \mathrm{ST}$, (b) $0040 \mathrm{ST}$, (c) $0050 \mathrm{ST}$, (d) $0100 \mathrm{ST}$, and (e) 0110 LST. The reflectivity contour interval is $5 \mathrm{dBZ}$, starting from $45 \mathrm{dBZ}$. Symbols indicate areas with maximum convergence weaker than $0.003 \mathrm{~s}^{-1}$ (cross) and stronger than $0.003 \mathrm{~s}^{-1}$ (circle) below $1 \mathrm{~km}$. A rectangle in (d) indicates the regions used for detailed analysis shown in Figs 5, 6, 7, 12, and 13. Thick grey contour marks the coastline of Jeju Island and thin grey contour lines have an interval of $200 \mathrm{~m}$.

Figure 4 shows the horizontal distributions of estimated reflectivity, horizontal wind, and convergence at 10-minute intervals between 0030 and $0110 \mathrm{ST}$, and includes a sequence of the horizontal distribution of the estimated reflectivity (contouring from $40 \mathrm{dBZ}$ at an interval of $5 \mathrm{dBZ}$, light shading between 40 and $45 \mathrm{dBZ}$, and dark shading between 50 and $55 \mathrm{dBZ}$ ) at a height of $1.9 \mathrm{~km}$. Regions with maximum convergences weaker (cross) and greater (circle) than $3 \times 10^{-3} \mathrm{~s}^{-1}$ below a height of $1 \mathrm{~km}$ are also indicated, and the grey thick and thin solid lines in each panel mark the coast and topography of Jeju Island, respectively. Each panel of Fig. 4 shows an area of $0.85^{\circ} \mathrm{E} \times 0.45^{\circ} \mathrm{N}$, the location of which was shifted approximately $10 \mathrm{~km}$ eastward every 10 minutes, following the system movement. At $0030 \mathrm{ST}$, the area with reflectivity over $45 \mathrm{dBZ}$ was located approximately $20 \mathrm{~km}$ from the northwestern shore of the island (Fig. 4a). A southwesterly wind of $10 \mathrm{~m} \mathrm{~s}^{-1}$ prevailed around the island at a height of $595 \mathrm{~m}$. Between 0030 and $0050 \mathrm{ST}$ (Fig. 4a-c), as the precipitation system approached the northwestern shore of the island, the convective cell (reflectivity $>50 \mathrm{dBZ}$ ) interior of the system enlarged horizontally. At $0050 \mathrm{ST}$ (Fig. 4c), the relatively strong southwesterly wind of $12 \mathrm{~m} \mathrm{~s}^{-1}$ was blowing between the system and the island $\left(33.25^{\circ} \mathrm{N}-33.35^{\circ} \mathrm{N}, 126.0^{\circ} \mathrm{E}-126.3^{\circ} \mathrm{E}\right)$. The related low-level convergence of less than $3 \times 10^{-3} \mathrm{~s}^{-1}$ was identified in the area between $126.0^{\circ} \mathrm{E}-126.3^{\circ} \mathrm{E}$ and $33.3^{\circ} \mathrm{N}-33.45^{\circ} \mathrm{N}$, but this was not well simulated by the NOTR experiment (not shown). Between 0050 and 0100 ST (Fig. 4c-d), the regions of reflectivity stronger than 40 and $45 \mathrm{dBZ}$ extended toward the southwest, where the convergence zone was located onshore at 0050 ST (Fig. 4c). At 0100 ST (Fig. 4d), the convective cell was situated near the northwestern coast of the island. In a region between $33.3^{\circ} \mathrm{N}-33.4^{\circ} \mathrm{N}$ and $126.06^{\circ} \mathrm{E}-126.3^{\circ} \mathrm{E}$, the low-level convergence (less than $3 \times 10^{-3} \mathrm{~s}^{-1}$ ) was continuously apparent, with a relatively strong southwesterly of $12 \mathrm{~m} \mathrm{~s}^{-1}$. Simultaneously, localized low-level convergence $\left(3 \times 10^{-3} \mathrm{~s}^{-1}\right)$ developed in the region bounded by $33.47^{\circ} \mathrm{N}-$ $33.53^{\circ} \mathrm{N}$ and $126.2^{\circ} \mathrm{E}-126.4^{\circ} \mathrm{E}$, off the northwestern shore of the island. As the convective cell moved further eastwards, and passed over the local low-level convergence between the system and the island, the relatively intensified convective cell developed at 0110 ST (Fig. 4e). At the same time, the regions of reflectivity stronger than 40 and $45 \mathrm{dBZ}$ extended horizontally.

Fig. 5. Temporal variations in the horizontal area of simulated reflectivity greater than $45 \mathrm{dBZ}$ (broken line) and $50 \mathrm{dBZ}$ (solid line) at a height of $1919 \mathrm{~m}$ from 0020 to 0110 ST. The analysis region A is shown in Fig. 4d by a rectangle.

Fig. 6. Vertical profiles of the expanded horizontal area during the approaching stage. (a) Enhanced horizontal area of reflectivity greater than $50 \mathrm{dBZ}$ from 0030 to $0100 \mathrm{ST}$. (b) Differences in horizontal area of reflectivity greater than $45 \mathrm{dBZ}$ (thin line) and $50 \mathrm{dBZ}$ (thick line) between CNTL and NOTR experiments (CNTL minus NOTR) at 0100 ST. 
To show the horizontal evolution of the convective cell at a height of $1919 \mathrm{~m}$, during the approaching stage, an analysis area (domain A) was selected within a $60 \mathrm{~km} \times 40 \mathrm{~km}$ area (Fig. 4d), which includes the reflectivity region exceeding $45 \mathrm{dBZ}$. The analysis domain was shifted at the same speed as the system (ca. $10 \mathrm{~m} \mathrm{~s}^{-1}$ ) as it moved through the area. Figure 5 indicates the time variation of the horizontal area of the convective cell (solid line), and also the range with reflectivity over $45 \mathrm{dBZ}$ (dashed line) at a height of $1.9 \mathrm{~km}$ during the approaching stage (0020-0110 ST). During this period, the area of the convective cell within domain A expanded gradually from 23 to $88 \mathrm{~km}^{2}$. Simultaneously, the horizontal area with reflectivity stronger than $45 \mathrm{dBZ}$ enlarged from 178 to $345 \mathrm{~km}^{2}$. Figure 6 a shows a vertical profile of the enhanced horizontal area of the convective cell from 0030 to $0100 \mathrm{ST}$ within domain $\mathbf{A}$, and the horizontal enlargement of the convective cell during this period was significant near the surface where it exceeded $40 \mathrm{~km}^{2}$, and an areal enlargement of over $10 \mathrm{~km}^{2}$ was apparent from the surface up to an altitude of $2.6 \mathrm{~km}$. Figure $6 \mathrm{~b}$ shows a vertical profile of the difference in the horizontal areas with reflectivity over $45 \mathrm{dBZ}$ (thin solid line) and $50 \mathrm{dBZ}$ (thick solid line) between the CNTL and NOTR experiments (CNTL minus NOTR) at $0100 \mathrm{ST}$, when the enhanced convective cell was located close to the northwestern coast of the island. As shown in Fig. 6b, the positive anomalies of the convective cell (thick solid line) were identified from the surface to the $1.5 \mathrm{~km}$ level. In addition, the positive anomalies larger than $10 \mathrm{~km}^{2}$ of the reflectivity region over $45 \mathrm{dBZ}$ (thin solid line) were concentrated below $1.5 \mathrm{~km}$. The positive anomalies exceeding $5 \mathrm{~km}^{2}$ with reflectivity over $45 \mathrm{dBZ}$ extended up to an altitude of $3 \mathrm{~km}$.

Fig. 7. Vertical profiles of vertical wind $(w)$, temperature $(\mathrm{T})$, dew point temperature (TD), and relative humidity (RH) during the approaching stage. (a) Maximum vertical velocity at $0030 \mathrm{ST}$ (thin broken line), $0100 \mathrm{ST}$ (thin solid line), and the difference between 0030 and 0100 ST (thick solid line: 0100 minus 0030 ST). (b) T (black solid line), TD (broken line), and RH (grey solid line) at the point of maximum vertical wind at $0100 \mathrm{ST}$.

Related to the enhancement of the convective cell during the approaching stage, the evolution of the updraft $(w)$ is shown in Fig. 7a. Vertical profiles of the maximum updraft at 0030 ST, 0100 ST, and the difference between them (0100 ST minus 0030 ST) within domain A are indicated by the dashed line, thin solid line, and thick solid line, respectively. The maximum updraft was less than $0.5 \mathrm{~m} \mathrm{~s}^{-1}$ below $1 \mathrm{~km}$ at $0030 \mathrm{ST}$. Within 30 minutes, the updraft had doubled to $1 \mathrm{~m} \mathrm{~s}^{-1}$ below a height of $1 \mathrm{~km}$, as the convective cell approached the northwestern coast of the island (Fig. $4 \mathrm{a}-\mathrm{d}$ ). The profiles of temperature ( $\mathrm{T}$, black solid line), dew point temperature (TD, dashed line), and relative humidity ( $\mathrm{RH}$, grey solid line) at the point of maximum updraft at $0100 \mathrm{ST}$ are shown in Fig. $7 \mathrm{~b}$. The surface temperature was $23^{\circ} \mathrm{C}$, and the temperature remained above $20^{\circ} \mathrm{C}$ to a height of $0.8 \mathrm{~km}$. An almost saturated layer was apparent from the surface to the $1 \mathrm{~km}$ level, where the updraft had doubled and RH was high (99\%). The updraft gradually increased up to a height of $4.6 \mathrm{~km}$ (Fig. 7a), and reached a maximum of $7.8 \mathrm{~m} \mathrm{~s}^{-1}$. Corresponding to the updraft profile at $0100 \mathrm{ST}$, the positive updraft anomaly between $0030 \mathrm{ST}$ and $0100 \mathrm{ST}$ attained a maximum of $2.3 \mathrm{~m} \mathrm{~s}^{-1}$ at a height of $4.6 \mathrm{~km}$. Above $4.6 \mathrm{~km}$, the positive updraft anomalies decreased gradually. Temperature decreased gradually with height, and had fallen to $0^{\circ} \mathrm{C}$ at $4.9 \mathrm{~km}$.

\subsection{The lee-side stage}

Fig. 8. Horizontal distributions of wind (vectors) at a height of $595 \mathrm{~m}$, estimated reflectivity (shades) at a height of $1919 \mathrm{~m}$, and convergence (symbols), simulated by the CNTL experiment for (a) $0130 \mathrm{ST}$, (b) $0140 \mathrm{ST}$, (c) $0150 \mathrm{ST}$, (d) $0200 \mathrm{ST}$, and (e) 0210 ST. The shaded regions and contours are as in Fig. 4. Rectangles in each panel indicate the regions used for detailed analysis shown in Figs 9, 10, 11, 12, and 13. 
Figure 8 shows the horizontal distributions of estimated reflectivity, horizontal wind, and convergence at intervals of 10 minutes between 0130 and $0210 \mathrm{ST}$; the thick grey solid line indicates the coastline of Jeju Island. At 0130 ST (Fig. 8a), the convective cell was located on the northern side of the island within domain $\mathbf{B}$ (rectangle in Fig. 8). Adjacent to the convective cell, a relatively weak westerly wind of $5 \mathrm{~m} \mathrm{~s}^{-1}$ blew along the northern side of the island. At the same time, convergence (grey cross) below $1 \mathrm{~km}$ on the eastern side of the island, driven by the relatively weak northwesterly $\left(6 \mathrm{~m} \mathrm{~s}^{-1}\right)$ from the north, converged with the relatively strong southwesterly $\left(11 \mathrm{~m} \mathrm{~s}^{-1}\right)$ from the southeastern slope of the island (at elevations below $500 \mathrm{~m}$ ), where a region of high RH (>96\%) was identified (Fig. 2a). Between 0140 and 0200 ST (Fig. 8b-d), the convective cell within domain $\mathbf{B}$ moved from the northern to the northeastern side of the island, passing on the stationary local convergence at low altitudes on the eastern slope. Consequently, at 0200 ST (Fig. 8d), a further horizontally enlarged convective cell was apparent on the northeastern side of the island. At 0210 ST (Fig. 8e), the relatively weakened convective cell was shown close to the east coast of the island. During 0140-0200 ST, the area with reflectivity over $45 \mathrm{dBZ}$ was gradually enlarged on the southeastern slope of the island, where the moist southwesterly wind was dominant in low altitudes (Figs. 2a and 8a-d). As the ambient southwesterly wind blowing over the gentle southeastern slope of an elliptic terrain (oriented west-east) is viewed in result of Petersen et al. (2005), the southwesterly wind on the southeastern slope of Jeju Island seems to generate a favorable condition for rainfall enhancement in a moist environment.

Fig. 9. Temporal variations in the horizontal area of simulated reflectivity greater than $50 \mathrm{dBZ}$ (solid line) at a height of 1919 $\mathrm{m}$ from 0130 to $0220 \mathrm{ST}$. The analysis region $\mathbf{B}$ is shown in Fig. 8 by rectangles.

Fig. 10. Vertical profiles of the expanded horizontal area during the lee-side stage. (a) Enhanced horizontal area of reflectivity greater than $50 \mathrm{dBZ}$ from 0140 to $0200 \mathrm{ST}$. (b) Differences in horizontal area of reflectivity greater than $45 \mathrm{dBZ}$ (thin line) and $50 \mathrm{dBZ}$ (thick line) between CNTL and NOTR experiments (CNTL minus NOTR) at 0200 ST.

Figure 9 shows the horizontal development of the convective cell within domain B at a height of $1919 \mathrm{~m}$, and at intervals of 10 minutes, between 0130 ST and 0220 ST. The horizontal extent of the convective cell at $0130 \mathrm{ST}$ was less than $5 \mathrm{~km}^{2}$. As the convective cell passed to the northeast of the island (Fig. 8a-c), its horizontal area gradually increased, to reach a maximum of $18 \mathrm{~km}^{2}$ on the eastern side of the island where the stationary convergence was identified (Fig. 8d). At $0210 \mathrm{ST}$, when the convective cell moved to the eastern coast of the island (Fig. 8e), the area of the convective cell decreased dramatically to less than $10 \mathrm{~km}^{2}$ (Fig. 9). The vertical profile of the enhanced horizontal area of the convective cell from 0140 to $0200 \mathrm{ST}$ within domain B (Fig. 8) is shown in Fig. 10a. The enlargement of the horizontal area of the convective cell to over $10 \mathrm{~km}^{2}$ was apparent between heights of $0.7 \mathrm{~km}$ to $3.3 \mathrm{~km}$. Figure $10 \mathrm{~b}$ shows the vertical profile of the difference in the horizontal area with reflectivity over 45 (thin solid line) and $50 \mathrm{dBZ}$ (thick solid line) between the CNTL and NOTR simulations (CNTL minus NOTR) at 0200 ST when the horizontally enlarged convective cell was located on the northeastern slope of the island (Fig. 8d). The positive anomalies of the convective cell (thick solid line) were concentrated between 3 and $4.5 \mathrm{~km}$ in height. The positive anomalies in the area with reflectivity over $45 \mathrm{dBZ}$ developed in two zones at heights of $1.5-3.5 \mathrm{~km}$ and $4.7-5.4 \mathrm{~km}$.

Fig. 11. Vertical profiles of vertical wind $(w)$, temperature (T), dew point temperature (TD), and relative humidity (RH) during the approaching stage. (a) Maximum vertical velocity at 0140 ST (thin broken line), 0200 ST (thin solid line), and the 
difference between 0140 and 0200 ST (thick solid line: 0200 minus 0140 ST). (b) T (black solid line), TD (broken line), and RH (grey solid line) at the point of maximum vertical wind at $0200 \mathrm{ST}$.

Related to the enhancement of the convective cell during the lee-side stage, the evolution of the updraft ( $w$ ) is shown in Fig. 11a. Vertical profiles of the maximum updraft at $0140 \mathrm{ST}, 0200 \mathrm{ST}$, and the difference between them (0200 ST minus 0140 ST) within domain B are shown by a thin dashed line, thin solid line, and thick solid line, respectively. At $0200 \mathrm{ST}$, the updraft stronger than $1 \mathrm{~m} \mathrm{~s}^{-1}$ was located above the $1 \mathrm{~km}$ level. The profiles of temperature ( $\mathrm{T}$, black solid line), dew point temperature (TD, dashed line), and relative humidity (RH, grey solid line) at the point of maximum updraft at $0200 \mathrm{ST}$ are shown in Fig. $11 \mathrm{~b}$. The temperature of $21^{\circ} \mathrm{C}$, and $\mathrm{RH}$ of between $95 \%$ and $99 \%$, below $1 \mathrm{~km}$ were relatively low compared with those recorded during the approaching stage (Fig. 7b). Temperature decreased gradually with height, and had fallen to $0^{\circ} \mathrm{C}$ at $4.9 \mathrm{~km}$. The updraft gradually increased above a height of $1 \mathrm{~km}$ (Fig. 11a), and the maximum updraft $\left(>6 \mathrm{~m} \mathrm{~s}^{-1}\right)$ was distributed up to a height of $5.9 \mathrm{~km}$. The updraft reached a maximum of $6.5 \mathrm{~m} \mathrm{~s}^{-1}$ at a height of $5.4 \mathrm{~km}$. Corresponding to the updraft profile at $0200 \mathrm{ST}$, the positive updraft anomalies (thick solid line in Fig. 11a) during the lee-side stage were located above a height of $1 \mathrm{~km}$, and the positive anomalies greater than $1 \mathrm{~m} \mathrm{~s}^{-1}$ were located in heights of $2.8-6 \mathrm{~km}$.

\section{Microphysical structure}

In this section, we consider the evolution of the hydrometeors and microphysical processes during the enhancement of convective cells in the approaching and lee-side stages.

\subsection{Structure of hydrometeors}

Vertical profiles of the maximum value of mixing ratios $\left(q_{v}, q_{c}, q_{r}, q_{g}\right.$, and $\left.q_{s}\right)$ of hydrometeors (vapor, cloud water, rain water, graupel, and snow) within domains $\mathbf{A}$ and $\mathbf{B}$ (depicted by rectangles in Figs. 4d and 8d), during the approaching (solid lines) and lee-side stages (dashed lines), respectively are shown in Fig. 12. Profiles of each mixing ratio at $0100 \mathrm{ST}$, and the increased mixing ratio from 0030 to $0100 \mathrm{ST}$ of the approaching stage are depicted by thin and thick solid lines, respectively. At $0100 \mathrm{ST}$, the convective cell was enhanced off the northwestern shore of the island by convergences caused by the strong southwesterly wind blowing between the convective cell and the island (Fig. 4d). At 0030 ST, before the enhancement, the convective cell was located $20 \mathrm{~km}$ from the northwestern shore of the island (Fig. 4a). Profiles of each mixing ratio at $0200 \mathrm{ST}$, and the increased mixing ratio from 0140 to $0200 \mathrm{ST}$ of the lee-side stage are shown in Fig. 12 by dashed thin and thick lines, respectively. At 0200 ST, the convective cell was enhanced on the lee side by a stationary local convergence region that developed as a result of the convergence of the weak northwesterly wind from the north of the island with the relatively strong southwesterly wind from its southeastern slope (Fig. 8d). At $0140 \mathrm{ST}$, the convective cell had not yet reached the local convergence on the lee side (Fig. 8b).

Fig. 12. Vertical profiles of mixing ratios of (a) vapor $\left(q_{v}, \mathrm{~g} \mathrm{~kg}^{-1}\right)$, (b) cloud water $\left(q_{c}, 10^{-1} \mathrm{~g} \mathrm{~kg}^{-1}\right)$, (c) rain water $\left(q_{r}, \mathrm{~g} \mathrm{~kg}^{-1}\right)$, (d) graupel $\left(q_{g}, 10^{-1} \mathrm{~g} \mathrm{~kg}^{-1}\right)$, and (e) snow $\left(q_{s}, 10^{-3} \mathrm{~g} \mathrm{~kg}^{-1}\right)$ at $0100 \mathrm{ST}$ (thin broken line) and $0200 \mathrm{ST}$ (thin solid line). Thick solid lines and thick broken lines in panels b-e indicate the increase in each mixing ratio during the approaching and lee-side stages, respectively.

As shown in Fig. 12a, the $q_{v}$ below a height of $0.8 \mathrm{~km}$ at 0100 and $0200 \mathrm{ST}$ was $17.5 \mathrm{~g} \mathrm{~kg}^{-1}$ and $16.5 \mathrm{~g} \mathrm{~kg}^{-1}$, respectively. Above $0.8 \mathrm{~km}, q_{v}$ decreased gradually with increasing altitude at both times. As shown in Fig. 12b, 
a $q_{c}$ of over $0.2 \mathrm{~g} \mathrm{~kg}^{-1}$ had developed above $0.4 \mathrm{~km}$ at $0100 \mathrm{ST}$, and above $1.5 \mathrm{~km}$ at $0200 \mathrm{ST}$. The $q_{c}$ gradually increased up to a height of $4.1 \mathrm{~km}$ during both stages, and was then maintained up to $5 \mathrm{~km}$ at around $15 \mathrm{~g} \mathrm{~kg}^{-1}$ and $12 \mathrm{~g} \mathrm{~kg}^{-1}$ during the approaching and lee-side stages, respectively. The increase of $q_{c}$ during the approaching and lee-side stages reached its maximum value at heights of $3 \mathrm{~km}$ and $3.6 \mathrm{~km}$, respectively. During the lee-side stage, an increase in $q_{c}$ of less than $5 \mathrm{~g} \mathrm{~kg}^{-1}$ was typical above $5.5 \mathrm{~km}$. At $0100 \mathrm{ST}$ (Fig. 12c), $q_{r}$ increased from $3.3 \mathrm{~g} \mathrm{~kg}^{-1}$ to $4.9 \mathrm{~g} \mathrm{~kg}^{-1}$ in a layer extending from the surface up to $3 \mathrm{~km}$, but then decreased gradually above 3 $\mathrm{km}$. The related increase of $q_{r}$ during the approaching stage (thick solid line, Fig. 12c) of over $1 \mathrm{~g} \mathrm{~kg}^{-1} \mathrm{occurred}$ between heights of 1 and $4 \mathrm{~km}$. At $0200 \mathrm{ST}, q_{r}$ increased from 2.5 to $4 \mathrm{~g} \mathrm{~kg}^{-1}$ between the surface and $3.6 \mathrm{~km}$, and then decreased slowly above $4 \mathrm{~km}$. During the lee-side stage (thick dashed line), $q_{r}$ increased by over $1 \mathrm{~g}$ $\mathrm{kg}^{-1}$ in a zone between 3 and $5.6 \mathrm{~km}$, which is higher than seen during the approaching stage. As shown in Fig. $12 \mathrm{~d}$, at $0100 \mathrm{ST}, q_{g}$ was over $0.5 \mathrm{~g} \mathrm{~kg}^{-1}$ above $4.2 \mathrm{~km}$, and over $2.0 \mathrm{~g} \mathrm{~kg}^{-1}$ above $5.4 \mathrm{~km}$. At $0200 \mathrm{ST}, q_{g}$ increased gradually from 0.5 to $2.5 \mathrm{~g} \mathrm{~kg}^{-1}$ between 4.2 and $6.1 \mathrm{~km}$. The increased $q_{g}$ during the lee-side stage was significant between 3.8 and $6.1 \mathrm{~km}$, showing a maximum increase at $6.1 \mathrm{~km}$. The profiles of $q_{s}$ are shown in Fig. 12e. At $0100 \mathrm{ST}$, a $q_{s}$ of over $0.001 \mathrm{~g} \mathrm{~kg}^{-1}$ had developed above $5.4 \mathrm{~km}$. During the approaching stage, an increase in $q_{s}$ of less than $0.25 \times 10^{-3} \mathrm{~g} \mathrm{~kg}^{-1}$ developed between 5.4 and $6 \mathrm{~km}$. At $0200 \mathrm{ST}$, a $q_{s}$ larger than $1.0 \times$ $10^{-3} \mathrm{~g} \mathrm{~kg}^{-1}$ was seen above $5.6 \mathrm{~km}$, but there was no increase in $q_{s}$ during the lee-side stage.

\subsection{Structure of microphysical process}

Vertical profiles of the rates of increase of the microphysical processes during the approaching and lee-side stages are shown in Fig. 13a and b, respectively. The rate of increase of vapor deposition to cloud water $\left(\mathrm{VD}_{\mathrm{VC}}\right)$ is indicated by the dotted line, of the conversion from cloud water to rain water $\left(\mathrm{CN}_{\mathrm{CR}}\right)$ by the dashed line, and of the collection of cloud water to rain water $\left(\mathrm{CL}_{\mathrm{CR}}\right)$ by the solid line. Fig. 13c contains the vertical profiles of the rates of snow melting to rain water $\left(\mathrm{ML}_{\mathrm{SR}}\right.$, black lines) and graupel melting to rain water ( $\mathrm{ML}_{\mathrm{GR}}$, grey lines) at $0030 \mathrm{ST}$ (thin line) and $0100 \mathrm{ST}$ (thick line) during the approaching stage. Fig. 13d contains the vertical profiles of the rates of snow melting to rain water $\left(\mathrm{ML}_{\mathrm{SR}}\right.$, black lines) and graupel melting to rain water $\left(\mathrm{ML}_{\mathrm{GR}}\right.$, grey lines) at $0140 \mathrm{ST}$ (thin line) and $0200 \mathrm{ST}$ (thick line) during the lee-side stage.

Fig. 13. Vertical profiles of increase rates of microphysical parameters. (a) Increase rate of vapor deposition to cloud water (VDvc, dotted line), collection from cloud water to rain water ( $\mathrm{CLCR}_{\mathrm{C}}$, solid line), and conversion from cloud water to rain water $\left(\mathrm{CN}_{\mathrm{CR}}\right.$, broken line) during the approaching stage. (b) Increase rates of $\mathrm{VD}_{\mathrm{VC}}, \mathrm{CL}_{\mathrm{CR}}$, and $\mathrm{CN}_{\mathrm{CR}}$ during the lee-side stage shown by the dotted, solid, and broken lines, respectively. (c) Maximum melting rates of graupel to rain water (MLGR) at $0030 \mathrm{ST}$ (grey thin solid line) and $0100 \mathrm{ST}$ (grey thick solid line), and maximum melting rates of snow to rain water (MLSR) at 0030 ST (black thin solid line) and 0100 ST (black thick solid line). (d) Maximum rates of ML $L_{\mathrm{GR}}$ (grey lines) and MLSR (black line) at 0140 ST (thin lines) and 0200 ST (thick lines).

The increase of $\mathrm{VD}_{\mathrm{VC}}$ during the approaching stage was evident from a height of $75 \mathrm{~m}$ (dotted line, Fig. 13a). The increase rate gradually increased to a height of $4.3 \mathrm{~km}$, and the maximum increase rate was $0.017 \times$ $10^{-3} \mathrm{~s}^{-1}$. Above $4.5 \mathrm{~km}$, a gradual decrease in $\mathrm{VD}_{\mathrm{VC}}$ was identified. During the lee-side stage (dotted line, Fig. $13 \mathrm{~b}$ ), the increase of $\mathrm{VD}_{\mathrm{VC}}$ was evident from a height of $1 \mathrm{~km}$. Compared with that during the approaching stage, a large increase in $\mathrm{VD}_{\mathrm{VC}}$ occurred between heights of 1 and $2 \mathrm{~km}$ during the lee-side stage. The increase rate of $\mathrm{VD}_{\mathrm{VC}}$ increased gradually between 2 to $6 \mathrm{~km}$, and the maximum increase rate of $0.015 \times 10^{-3} \mathrm{~s}^{-1}$ was at $6.1 \mathrm{~km}$. The increase rate of $\mathrm{CN}_{\mathrm{CR}}$ during the approaching stage (dashed line, Fig. 13a) had two peak heights at 3 and 5 $\mathrm{km}$. Similarly, the increase rate of $\mathrm{CN}_{\mathrm{CR}}$ during the lee-side stage showed two peak heights (dashed line in Fig. 13b), but at the higher altitudes of 3.5 and $6 \mathrm{~km}$. The increase of $\mathrm{CL}_{\mathrm{CR}}$ during the approaching stage (solid line, 
Fig. 13a) was apparent above $1.5 \mathrm{~km}$, and reached a maximum at $4.3 \mathrm{~km}$ of $0.014 \times 10^{-3} \mathrm{~s}^{-1}$. During the lee-side stage (solid line, Fig. 13b), the increase in $\mathrm{CL}_{\mathrm{CR}}$ became evident above $1.9 \mathrm{~km}$, and the maximum increase rate of $0.015 \times 10^{-3} \mathrm{~s}^{-1}$ occurred at a relatively high altitude of $5.6 \mathrm{~km}$.

The rate of increase of $\mathrm{ML}_{\mathrm{GR}}$ increased in the period from 0030 to $0100 \mathrm{ST}$ during the approaching stage, and most significantly between the heights of 4.1 and $4.8 \mathrm{~km}$ (grey lines, Fig. 13c). Between 0140 and $0200 \mathrm{ST}$ during the lee-side stage (grey lines, Fig. 13d), the rate of increase of $\mathrm{ML}_{\mathrm{GR}}$ was greatest between 3.6 and 4.6 $\mathrm{km}$ in altitude, but decreased between 4.6 and $5.1 \mathrm{~km}$. During the lee-side stage, ML $_{\mathrm{SR}}$ decreased significantly between 4.3 and $5.1 \mathrm{~km}$ (black lines, Fig. 13d). The increase and decrease rates of ML $_{\mathrm{SR}}$ are shown at heights of $5.1 \mathrm{~km}$ and $4.8 \mathrm{~km}$, respectively, between $0030 \mathrm{ST}$ and $0100 \mathrm{ST}$, by the black lines in Fig. 13c.

\section{Discussion}

As discussed in sections 3 and 4, the enhancement of the convective cells associated with the precipitation system that passed off the northwestern shore and lee side of Jeju Island on 6 July 2007, showed related enhancement of the updraft and hydrometeors. The distinguishing features of the updraft, hydrometeors, and microphysical processes within the enhanced convective cells during the two stages are discussed in this section.

In Fig. 14, the heights of the positive anomalies of the convective cells, updraft, hydrometeors $\left(q_{c}, q_{r}, q_{g}, q_{s}\right.$, and $-q_{s}$ ) and microphysical processes $\left(\mathrm{VD}_{\mathrm{VC}}, \mathrm{CN}_{\mathrm{CR}}, \mathrm{CL}_{\mathrm{CR}}, \mathrm{ML}_{\mathrm{GR}}, \mathrm{ML}_{\mathrm{SR}}\right.$, and $\left.-\mathrm{ML}_{\mathrm{SR}}\right)$ during the approaching (0030-0100 ST) and lee-side (0140-0200 ST) stages are summarized. A and L on the horizontal axes of Fig. 14 indicate the approaching stage and the lee-side stage, respectively. The cross on each bar indicates the height of the maximum anomaly for each parameter. A dotted line indicates the height of the $0^{\circ} \mathrm{C}$ level. Figure 15 shows schematic diagrams of the two enhancements of convective cells, and the hydrometeors during the approaching stage and the lee-side stage are illustrated.

Fig. 14. Height distributions of the increase of the convective region (reflectivity $>50 \mathrm{dBZ}$ ), updraft, mixing ratios of cloud water $\left(q_{c}\right)$, rain water $\left(q_{r}>1 \mathrm{~g} \mathrm{~kg}^{-1}\right)$, graupel $\left(q_{g}\right)$, snow $\left(q_{s}\right)$, and the rates of vapor deposition to rain water (VDvc), conversion from rain water to cloud water $\left(\mathrm{CN}_{\mathrm{CR}}\right)$, collection from cloud water to rain water $\left(\mathrm{CL}_{\mathrm{CR}}\right)$, graupel melting to rain water (MLGR), and snow melting to rain water (MLsR) during the approaching (A, black bars) and lee-side stages ( $\mathbf{L}$, grey bars). The black cross denotes the height of the maximum increase. The height of the $0^{\circ} \mathrm{C}$ level is indicated by the dotted line.

Fig. 15. Schematic illustrations of the enhancements of the microphysical parameters in (a) the approaching stage, and (b) the lee-side stage of the 6 July 2007 precipitation system. Vertical cross-sections of the precipitation area are shown as grey shading. Black arrows indicate the low-level winds. Grey arrows depict local updraft in the vicinity of the terrain. White arrows indicate the terrain-induced circulatory winds at low altitudes. Symbols inside the precipitation area represent the increased hydrometeors. Dark grey circles and light grey ellipses indicate cloud water and rain water, respectively. White diamond indicates graupel. The height of the thick solid line in each panel shows the topography of Jeju Island.

\subsection{Approaching stage microphysical structure}

During the approaching stage, the convective cell (defined as the portion with an estimated reflectivity $>$ $50 \mathrm{dBZ}$ ) intensified significantly over the northwestern coastal area of the island. This intensification was evident in the expansion of the horizontal area of the convective cell at a height of $1.9 \mathrm{~km}$, and the increased positive anomaly of its vertical profile (Figs. 5 and 6a). These simulated results are consistent with the results of 
dual-Doppler radar analysis reported by Lee et al. (2012).

During this period, the positive anomaly of the convective cell was significant from the surface up to 4.2 $\mathrm{km}$, with the maximum value occurring at the surface (Figs. 14 and 15a). This vertical structure of the convective cell is similar to that described by Lee et al. (2012) based on a dual-Doppler radar dataset, who observed that the area of radar reflectivity greater than $48 \mathrm{dBZ}$ extended from the surface to a height of $5.5 \mathrm{~km}$ as the precipitation system approached the northwestern coast of the island. Corresponding to this system enhancement, they identified a localized updraft region between the southern part of the system and the island. As the distance between the system and the island narrowed, the southwesterly wind blowing between them strengthened; the resultant local updraft appears to be crucial in the enhancement of the convective cell on the northwestern shore of the island. Similarly to Lee et al. (2012), in this study, a local updraft region was simulated by the CNTL experiment (Fig. 4b-d), but not by the NOTR experiment. Corresponding to the updraft off the northwestern shore of the island, the positive updraft anomalies during the approaching stage were seen below $1.5 \mathrm{~km}$ (Figs. 7a and 14). Simultaneously, the difference in the horizontal area of the convective cell at 0100 ST between the CNTL and NOTR experiments was concentrated below $1.5 \mathrm{~km}$ (Fig. 6b).

With the positive anomalies of the convective cell and updraft developing at relatively low altitudes off the northwestern shore of the island, a high vapor mixing ratio $\left(17 \mathrm{~g} \mathrm{~kg}^{-1}\right)$ localized below $0.8 \mathrm{~km}$ (Fig. 12a). With the high $q_{v}$ at low altitudes, a positive $\mathrm{VD}_{\mathrm{VC}}$ anomaly was apparent from the surface up to $6 \mathrm{~km}$, and the maximum anomaly was at $4.5 \mathrm{~km}$ (Fig. 14). Consequently, a positive $q_{c}$ anomaly developed between the surface and a height of $5.3 \mathrm{~km}$, with the maximum anomaly at $2.7 \mathrm{~km}$ (Fig. 14 and dark grey circles in Fig. 15a), while the melting layer was located at $4.9 \mathrm{~km}$. With the large increase of $q_{c}$, the microphysical processes of $\mathrm{CN}_{\mathrm{CR}}$ and $\mathrm{CL}_{\mathrm{CR}}$ showed positive anomalies, but mainly below the melting layer, showing a maximum at $3.1 \mathrm{~km}$ and 4.3 $\mathrm{km}$, respectively (Fig. 14). Consequently, the positive $q_{r}$ anomalies were concentrated in a zone between 1 and $4.2 \mathrm{~km}$ in height (Fig. 14 and light grey ellipses in Fig. 15a). The positive updraft anomalies persisted to a height of $5.8 \mathrm{~km}$, with the maximum at $4.5 \mathrm{~km}$ (Fig. 14). Between the heights of 1.5 and $5.2 \mathrm{~km}$, the increase in the melting of graupel to form rain water was significant (Fig. 14 and white diamonds in Fig. 15a).

Most of the hydrometeors increased from the surface to the region below the melting layer during the approaching stage. This explains the important role of the warm rain process in enhancing the convective cell over the northwestern shore of the island. Abundant vapor at low altitudes seems to have been supplied to the interior of the convective cell by the locally generated updraft that developed between the system and the island. The moisture supplied by this updraft from the surface could enhance the convective cell, but mainly below the melting layer.

\subsection{Lee-side stage microphysical structure}

During the lee-side stage, the convective cell intensified significantly on the eastern slope of the island, where the terrain-modified go-around northwesterly wind from the north converged with the relatively strong and moist southwesterly wind on the southeastern slope. The intensification was evident in the expansion of the horizontal area of the convective cell at a height of $1.9 \mathrm{~km}$, and the increased positive anomaly of its vertical profile (Figs. 9 and 10a). These simulated results were implied by the dual-Doppler radar analysis in Lee et al. (2012). In their study, due to the limited observational range of dual-Doppler radar, the complete horizontal wind distribution at low altitudes was not available; however, the important role of the go-around airflow (i.e., the flow of air around Mt. Halla rather than over it) and the southwesterly upslope wind in generating stationary convergence on the lee side was mentioned.

During this period, the positive anomaly of the convective cell was significant between heights of 1 and $3.8 \mathrm{~km}$, with the maximum at $2.8 \mathrm{~km}$ (Figs. 14 and 15b). Toward the enhanced convective cell, the relatively weak northeasterly wind from the northern side of the island converged with the moist southwesterly $(\mathrm{RH}>$ 
$96 \%$ ) from the southeastern slope (elevation $<500 \mathrm{~m}$ ). The southwesterly wind brought low-level air having high $q_{v}$ of 15-16 $\mathrm{g} \mathrm{kg}^{-1}$ to the eastern slope from the southern shore of island. Lee et al. (2012) identified this

moist southwesterly upslope wind as a critical element in the generation of the local moist updraft that caused the enhancement of the convective cell on the lee side. With regard to the upslope wind in this study, the positive anomalies of the updraft were identified between heights of 1 and $6.3 \mathrm{~km}$, and the maximum was at 5.5 $\mathrm{km}$, which is above the melting layer.

Related to the positive updraft anomalies at the higher altitudes than seen in the approaching stage (Fig. 14) are the positive $q_{c}$ anomalies evident above $2 \mathrm{~km}$ (dark grey circles in Fig. 15b). With this $q_{c}$ distribution, the microphysical processes from $q_{c}$ to $q_{r}$ of $\mathrm{CN}_{\mathrm{CR}}$ and $\mathrm{CL}_{\mathrm{CR}}$ developed positive anomalies above $1.5 \mathrm{~km}$ (Fig. 14). In particular, the maximum anomalies of the $\mathrm{CL}_{\mathrm{CR}}$ were identified at $5.3 \mathrm{~km}$, which is above the melting layer. Consequently, the positive $q_{r}$ anomalies were concentrated between heights of 3.1 and $5.6 \mathrm{~km}$ (light blue ellipses in Fig. 15b). Above $5.6 \mathrm{~km}$, a continuous increase in updraft was seen during the lee-side stage. Related to this increasing updraft, positive $q_{g}$ anomalies are apparent in the height range $3.8-6.0 \mathrm{~km}$, with the maximum at 6 $\mathrm{km}$. Between the heights of 4.9 and $6 \mathrm{~km}$, the melting rate of graupel was hardly distributed, and this suggests the growth of graupel above the melting layer. In addition, a decrease in snow and increase in cloud water occurred in this layer (Fig. 14). The growth of the hydrometeors above the melting layer was also reflected in the Doppler radar analysis of Lee et al. (2012). They mentioned the area of high reflectivity ( $\geq 50 \mathrm{dBZ})$ localized at the relatively high altitude of $7 \mathrm{~km}$, which provides evidence of the moist nature of the southwesterly upslope wind. As the southwesterly upslope wind converged with the terrain-modified go-around weak northwesterly from the north, the local moist convergence was able to remain stationary on the eastern slope of the island. Under these conditions, when the convective cell arrived it was re-intensified at relatively higher altitudes.

However, in a similarly moist environment, and with prevailing southwesterly winds at low altitudes, Lee et al. (2010) reported the rapid dissipation of convective cell on the northeastern slope of the island. In that case, a relatively strong southwesterly wind $(F r=0.55)$ resulted in the partial vertical diversion of the winds over the island. This generated a dry downdraft on the northeastern slope of the mountain, which in turn resulted in the dissipation of the convective cell. In contrast, with a relatively weak southwesterly wind $(F r=0.2)$ in this study, the horizontal rerouting of the moisture prevailed, and very little dry descending air was generated. This allowed the convective cell to reach the lee side of the island, where the local moist convergence was stationary, without the dissipation of the system. These results emphasize the important role that a fairly weak southwesterly wind $(F r=0.2)$ plays, in addition to a moist environment at low altitudes, if the enhancement of the convective cell on the lee side of the island is to be generated.

Therefore, during the lee-side stage in this study, the increase of the hydrometeors was seen at both low altitudes and above the freezing level. That suggests that both the warm and cold rain processes are important in enhancing the convective cell on the eastern side of the island. Regarding the increase of cold hydrometeors, both the stationary terrain-generated convergence with a fairly low $\operatorname{Fr}(0.2)$, and the southwesterly upslope wind that supplies moist air from the southern side of the island to the inside of the convective cell, seem to be crucial elements.

\section{Conclusions}

The convective cells within a precipitation system over Jeju Island strengthened significantly as it passed the northwestern shore of the island, and then again as it moved to the lee side of the isolated Mt. Halla on 6 July 2007. The two enhancements of convective cells in the vicinity of the island were accurately reproduced by 
a cloud-resolving storm simulator (CReSS) with a resolution of $1 \mathrm{~km}$, and we have shown here the microphysical structure and evolution of the system during these two phases of enhancement. A control experiment (CNTL), which included full model physics and actual topography, simulated the terrain-modified go-around airflow (i.e., the flow of air around Mt. Halla rather than over it) with a relatively low $\operatorname{Fr}(0.2)$, and the two related moist regions $(\mathrm{RH}>96 \%)$ on the northwestern and the southeastern sides of the island.

Regarding the enhancement of the convective cell off the northwestern shore of the island, an increased updraft developed from the sea surface to an altitude of $1.5 \mathrm{~km}$ (maximum: $4.5 \mathrm{~km}$ ), where moisture levels were very high $\left(17 \mathrm{~g} \mathrm{~kg}^{-1}\right)$. With the increased updraft and plentiful moisture at low altitudes, cloud water increased from the sea surface upwards, and reached a maximum at $2.7 \mathrm{~km}$. Consequently, the microphysical processes that produce rain water from cloud water (e.g., conversion and collection) were significant below $4.3 \mathrm{~km}$; thus, the increase in rain water was seen between heights of 1 and $4.2 \mathrm{~km}$, and mainly below the freezing level (4.9 $\mathrm{km})$. In terms of enhancement of the convective cell on the lee side, the terrain-generated stationary convergence and the increased updraft above $1 \mathrm{~km}$ (maximum: $5.5 \mathrm{~km}$ ) were evident. The high levels of moisture on the southeastern slope of the island were supplied to the convective cell by the southwesterly upslope wind at low altitudes. With the moist updraft above $1 \mathrm{~km}$, cloud water increased above $1.5 \mathrm{~km}$ before the microphysical processes that produce rain water became significantly active in a layer between 1.5 and $5.3 \mathrm{~km}$, which extended above the freezing level $(4.9 \mathrm{~km})$. Consequently, above the freezing level, a decreased melting rate of graupel and an increase in cloud water were seen during the enhancement of the convective cell on the lee side.

The precipitation system of 6 July 2007 was enhanced significantly off the northwestern shore and to the lee side of the elliptical and steep topography of Jeju Island. The enhancements of convective cells within this system occurred in the vicinity of terrain having a relatively small horizontal scale; however, the microphysical structure during the two phases of enhancements of the convective cells differed. Combining the results of the present study with those of Lee et al. (2012), we conclude that the primary enhancement off the northwestern shore of the island was caused mainly by the warm rain process due to a combination of the regional updraft at low altitudes caused by the system-terrain interaction, and the plentiful supply of moisture at the sea surface. Regarding the enhancement of the convective cell on the lee side, hydrometeors increased below and above the freezing level due to both the stationary terrain-generated convergence (under conditions of $F r=0.2$ ), and the southwesterly upslope wind in a moist environment; consequently, both of the active warm and cold rain processes were important to the development of the enhancement. The future studies using observational dataset are required to be built on the present study toward extending our understanding of microphysical structure of orographically-enhanced rainfall system in the vicinities of an elliptical and steep terrain such as Jeju Island.

\section{Acknowledgements}

We would like to express our appreciation to Dr. S. Shimizu of National Institute for Earth science and Disaster prevention, Mr. M. Kato of the Hydrospheric Atmospheric Research Center of Nagoya University, and Mr. A. Sakakibara of Chuden CTI Co., Ltd. for giving useful advice for CReSS running and analyses. We are grateful to Profs. K. Tsuboki and T. Shinoda, and members of the Laboratory of Meteorology of HyARC, Nagoya University, Japan for providing helpful suggestions and comments. This study was supported by formation of a virtual laboratory for diagnosing the Earth's climate system (VL), defrayed by the Ministry of Education, Culture, Sports, Science and Technology of Japan (MEXT). One of the authors (Keun-Ok Lee) is supported by MEXT, as a doctoral student in the Graduate School of Environmental Studies, Nagoya University, Japan. This study was partly supported by the Japan Science and Technology Corporation and a Grant-in-Aid for Scientific Research from the Japan Society for the Promotion of Science. This research was partly supported by the 
National Research Foundation of Korea (NRF) through a grant provided by the Korean Ministry of Education, Science \& Technology (MEST) in 2013 (No. K201300037). Partly, this work was funded by the Korea Meteorological Administration Research and Development Program under Grant CATER 2012-2071.

\section{References}

Asselin, R., 1972: Frequency filter for time integrations. Mon. Wea. Rev., 100, 487-490.

Chiao, S., and Y.-L. Lin, 2003: Numerical modeling of an orographically enhanced precipitation event associated with tropical storm Rachel over Taiwan. Wea. Forecasting, 18, 325-344.

Cotton, W. R., G. J. Tripoli, R. M. Rauber, and E. A. Mulvihill, 1986: Numerical simulation of the effects of varying ice crystal nucleation rates and aggregation processes on orographic snowfall. J. Climate Appl. Meteor., 25, 1658-1680.

Hobbs, P. V., R. A., Houze, T. J. Matejka, 1975: The dynamical and microphysical structure of an occluded frontal system and its modification by orography. J. Atmos. Sci., 32, 1542-1562.

Houze, R. A. Jr., 2012: Orographic effects on precipitating clouds. Rev. Geophys., doi:10.1029/2011RG000365.

Houze, R. A. Jr., and S. Medina, 2005: Turbulence as a mechanism for orographic precipitation enhancement. J. Atmos., Sci., 62, 3599-3623.

Ikawa, M., and K. Saito, 1991: Description of a nonhydrostatic model developed at the Forecast Research Department of the MRI. MRI Tech. Rep. 28, Meteorological Research Institute, 238 pp. [Available online at http://www.mri-jma.go.jp/Publish/Technical/DATA/VOL_28/28_en.html.]

Jiang, Q., 2003: Moist dynamics and orographic precipitation. Tellus, 55A, 301-316.

Klemp, J. B., and R. B. Wilhelmson, 1987: The simulation of three-dimensional convective storm dynamics. J. Atmos. Sci., 35, 1070-1096.

Lee, K.-O., S. Shimizu, M. Maki, C.-H. You, H. Uyeda, and D.-I. Lee, 2010: Enhancement mechanism of the 30 June 2006 precipitation system observed over the northwestern slope of Mt. Halla, Jeju Island, Korea. Atmos. Res., 97, 343-358.

Lee, K.-O., H. Uyeda, S. Shimizu and D.-I. Lee, 2012: Dual-Doppler radar analysis of the enhancement of a precipitation system on the northern side of Mt. Halla, Jeju Island, Korea on 6 July 2007. Atmos. Res., 118, 133-152.

Li, J., Y.-L. Chen, and W.-C. Lee, 1997: Analysis of a heavy rainfall event during TAMEX. Mon. Wea. Rev., $125,1060-1082$.

Lin, Y.-L., 2007: Mesoscale dynamics, Cambridge University Presss, 630 pp.

Lin, Y.-L., R. D. Farley, and H. D. Orville, 1983: Bulk parameterization of the snow field in a cloud model. J. Appl. Meteor., 22, 1065-1092.

Lin, Y.-L. and T.-A. Wang, 1996: Flow regimes and transient dynamics of two-dimensional stratified flow over an isolated mountain ridge. J. Atmos. Sci., 53, 139-158.

Miles, J.W. and H.E. Huppert, 1969: Lee waves in a stratified flow. Part 4: Perturbation approximation. J. Fluid Mech., 35, 497-525.

Murakami, M., 1990: Numerical modeling of dynamical and microphysical evolution of an isolated convective cloud - The 19 July 1981 CCOPE cloud. J. Meteor. Soc. Japan, 68, 107-128.

Murakami, M., T. L. Clark, and W. D. Hall, 1994: Numerical simulations of convective snow clouds over the Sea of Japan; Two-dimensional simulations of mixed layer development and convective snow cloud formation. J. Meteor. Soc. Japan, 72, 43-62.

Olafsson, H, 2000: The impact of flow regimes on asymmetry of orographic drag at moderate and low Rossby numbers. Tellus, 52A, 365-379. 
Petersen, G. N., H. Olafsson and J. E. Kristjansson, 2003: Flow in the lee of idealized mountains and Greenland. J. Atmos. Sci., 60, 2183-2195.

Petersen, G. N., J. E. Kristjansson, and H. Olafsson, 2005: The effect of upstream wind direction on atmospheric flow in the vicinity of a large mountain. Q. J. R. Meteorol. Soc., 131, 1113-1128.

Reeves, H. D., Y. L. Lin, 2007: The effect of a mountain on the propagation of a preexisting convective system for blocked and unblocked flow regimes. J. Atmos. Sci., 64, 2401-2421.

Rowe, A. K., 2011: A polarimetric radar analysis of convection observed during NAME and TiMREX. Ph.D. Thesis, Colorado State University.

Segami, A., K. Kurihara, H. Nakamura, M. Ueno, I. Takano, and Y. Tatsumi, 1989: Operational mesoscale weather prediction with Japan Spectral Model. J. Meteor. Soc. Japan, 67, 907-923.

Smith, R. B., 1979: The influence of mountains on the atmosphere. Adv. Geophys. 21, 87-230.

Smith, R. B., 1980: Linear theory of stratified hydrostatic flow past an isolated mountain. Tellus, 32, 348-364.

Smolarkeiwicz, P. K., R. M. Rasmussen, and T. L. Clark, 1988: On the dynamics of Hawaiian cloud bands: Island forcing. J. Atmos. Sci., 45, 1872-1905.

Smolarkeiwicz, P. K., and R. Rotunno, 1989: Low Froude number flow past three-dimensional obstacles. Part I : Baroclinically generated Lee vortices. J. Atmos. Sci., 46, 1154-1164.

Tsuboki, K., and A. Sakakibara, 2001: CReSS User's Guide, 2 ${ }^{\text {nd }}$ edition, 210 pp. [available from http://www.rain.hyarc.nagoya-u.ac.jp/ tsuboki/cress_html/src_cress/CReSS2223_users_guide_eng.pdf].

Tsuboki, K., and A. Sakakibara, 2002: Large-scale parallel computing of cloud resolving storm simulator. High Performance Computing: Proceedings of the Fourth International Symposium on High Performance Computing, H. P. Zima et al., Eds., Springer, 243-259.

Woods, C. P., M. T., Stoelinga, J. D. Locatelli, and P. V. Hobbs, 2005: Microphysical processes and synergistic interaction between frontal and orographic forcing of precipitation during the 13 December 2001 IMPROVE-2 event over the Oregon Cascades. J. Atmos. Sci., 62, 3493-3519.

Xu, W., E. Zipser, Y.-L. Chen, C. Liu, Y-C. Liou, W.-C. Lee, and B. J.-D. Jou, 2012: An orography-associated extreme rainfall event during TiMREX: Initiation, storm evolution, and maintenance. Mon. Wea. Rev. 140, 2555-2574.

Yuter, S. E., and R. A. Houze, Jr., 2003: Microphysical modes of precipitation growth determined by S-band vertically pointing radar in orographic precipitation during MAP. Quart. J. Roy. Meteor. Soc., 129, 455476. 
Table 1. Specifications of CReSS.

\begin{tabular}{|c|c|}
\hline Model feature & Description \\
\hline Basic equation & $\begin{array}{l}\text { Quasi-compressible nonhydrostatic Navier- } \\
\text { Stokes equations with a map factor }\end{array}$ \\
\hline Projection & Lambert conformal conic \\
\hline Vertical coordinate & Terrain-following \\
\hline Grid & $\begin{array}{l}\text { Staggered Arakawa C type in the horizontal } \\
\text { and Lorenz type in the vertical }\end{array}$ \\
\hline Advection scheme & $\begin{array}{l}\text { Antiflux form with fourth-order central } \\
\text { differential }\end{array}$ \\
\hline Diffusion scheme & Fourth-order central differential method \\
\hline Turbulent closure & 1.5-order closure scheme \\
\hline Time splitting & $\begin{array}{l}\text { Horizontally explicit and vertically implicit } \\
\text { for sound waves }\end{array}$ \\
\hline Precipitation scheme & $\begin{array}{l}\text { Bulk cold-rain scheme (predicting } q_{v}, q_{c}, q_{r} \text {, } \\
\qquad q_{i}, q_{s}, q_{g}, N_{i}, N_{s} \text {, and } N_{g} \text { ) }\end{array}$ \\
\hline Surface layer & Bulk method similar to Segami et al. (1989) \\
\hline Lower boundary & $\begin{array}{l}\text { Rigid; temperature is forecast using a } 30 \text { - } \\
\text { layer one-dimensional model }\end{array}$ \\
\hline Upper boundary & Rigid lid with absorbing layer \\
\hline Lateral boundary & Radiative nesting boundary condition \\
\hline
\end{tabular}



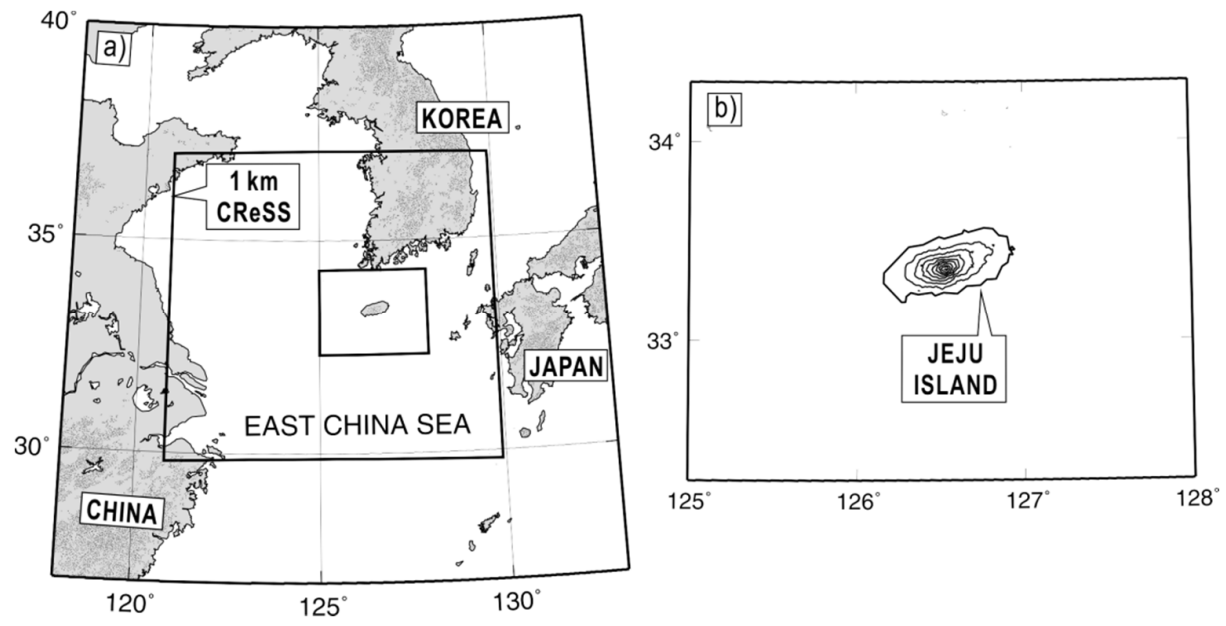

Fig. 1. Jeju Island: location and topography. The larger inner domain [square in (a)] was used in numerical simulations using a cloud-resolving storm simulator (CReSS) with a resolution of $1 \mathrm{~km}$. Contours show surface elevation. Smaller inner domain [square in (a)] indicates the topography of Jeju Island with a contour interval of $200 \mathrm{~m}$ [shown in (b)].

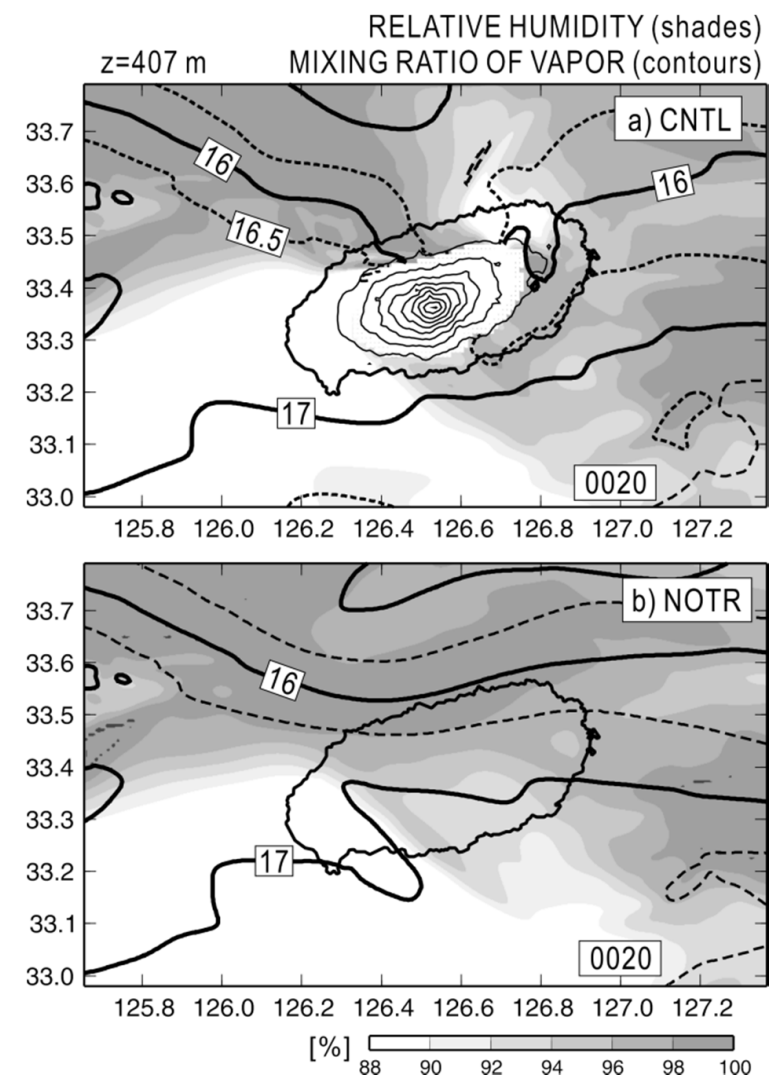

Fig. 2. Distributions of the simulated relative humidity (\%, grey) and mixing ratio of vapor $\left(\mathrm{g} \mathrm{kg}^{-1}\right.$, contours) at a height of $407 \mathrm{~m}$ for (a) CNTL and (b) NOTR experiments at $0020 \mathrm{ST}$. 


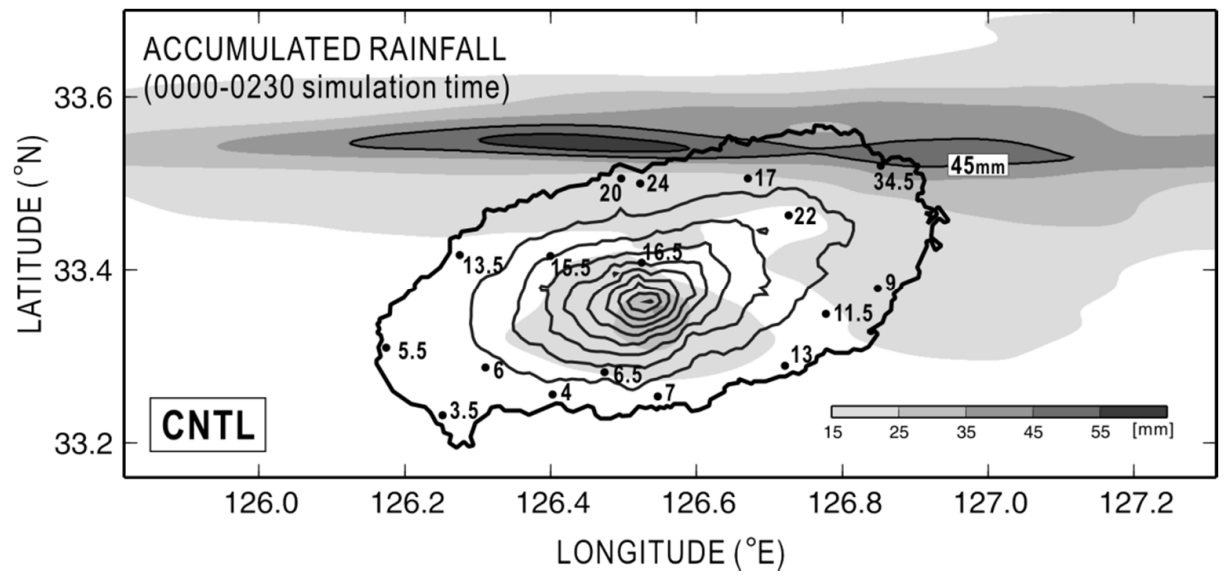

Fig. 3. Rainfall amounts (mm) recorded by 17 rain gauges (dots) on Jeju Island between 0000 and 0130 LST on 6 July 2007. Rainfall amount simulated by CNTL over the whole calculation period ( 2.5 hours) is indicated by shading with thin contours of $45 \mathrm{~mm}$ and $55 \mathrm{~mm}$. The contour lines show surface elevation (interval: $200 \mathrm{~m}$ ). 
a) $0030 \mathrm{ST}$

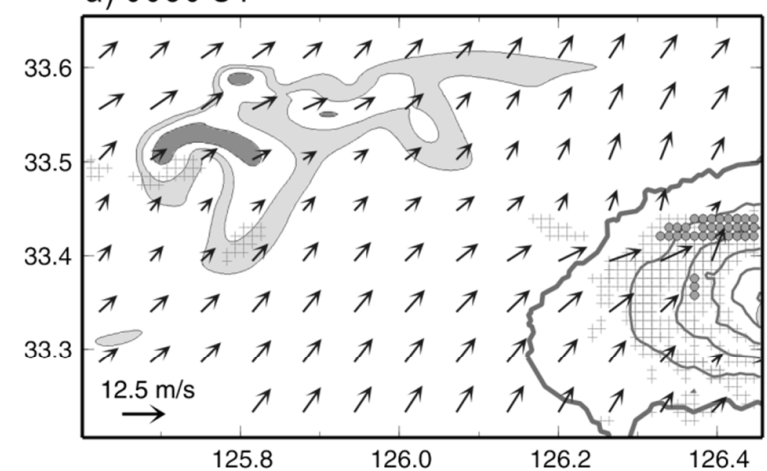

c) $0050 \mathrm{ST}$

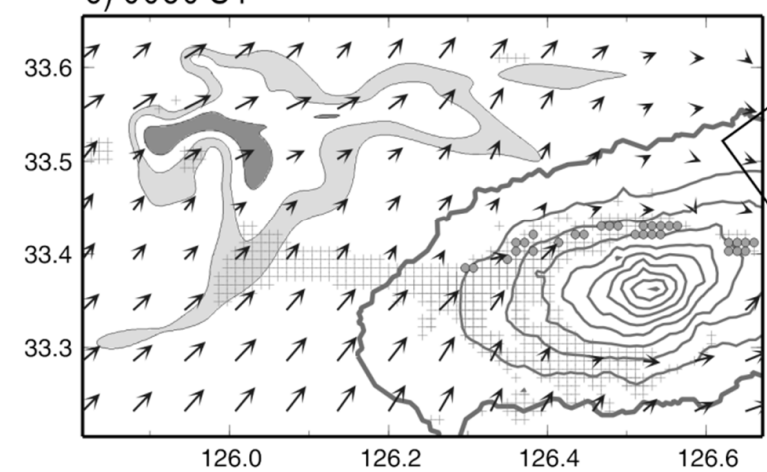

e) $0110 \mathrm{ST}$

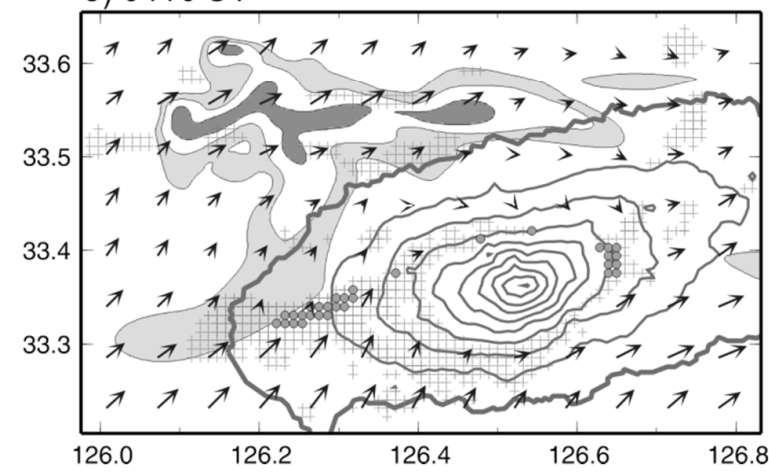

b) $0040 \mathrm{ST}$

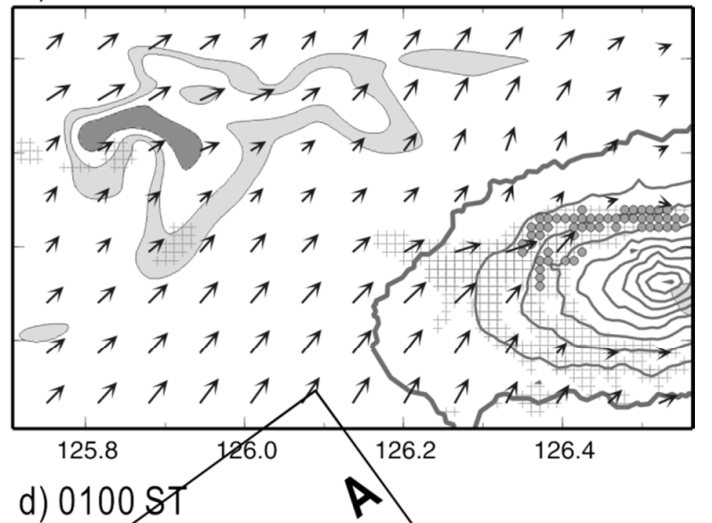

d) 010081

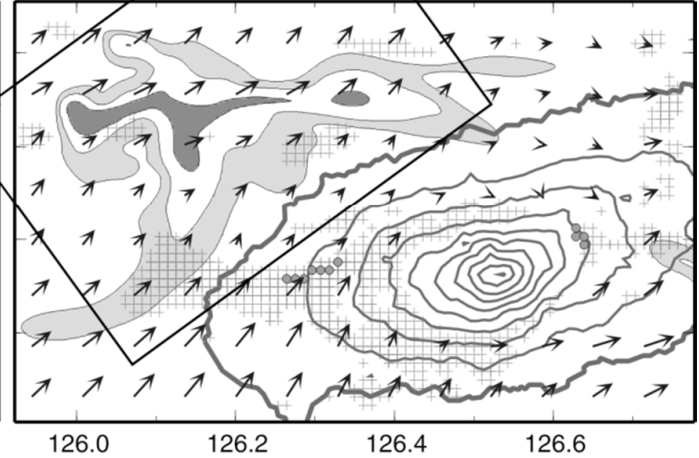

HORIZONTAL REFLECTIVITY $(z=1919 \mathrm{~m})$

[dBZ] $40 \quad 45 \quad 50 \quad 55$

HORIZONTAL WIND $(z=595 \mathrm{~m})$

$\stackrel{12.5 \mathrm{~m} / \mathrm{s}}{\longrightarrow}$

CONVERGENCE $(\mathrm{z}=$ below $1 \mathrm{~km})$

$+<3 \times 10^{-3} s^{-1}$

c $>3 \times 10^{-3} \mathrm{~S}^{-1}$

Fig. 4. Horizontal distributions of the simulated wind (vectors) at a height of $595 \mathrm{~m}$, reflectivity (shades) at a height of 1919 $\mathrm{m}$, and convergence (symbols), simulated by the CNTL experiment for (a) $0030 \mathrm{ST}$, (b) $0040 \mathrm{ST}$, (c) $0050 \mathrm{ST}$, (d) $0100 \mathrm{ST}$, and (e) 0110 LST. The reflectivity contour interval is $5 \mathrm{dBZ}$, starting from $45 \mathrm{dBZ}$. Symbols indicate areas with maximum convergence weaker than $0.003 \mathrm{~s}^{-1}$ (cross) and stronger than $0.003 \mathrm{~s}^{-1}$ (circle) below $1 \mathrm{~km}$. A rectangle in (d) indicates the regions used for detailed analysis shown in Figs 5, 6, 7, 12, and 13. Thick grey contour marks the coastline of Jeju Island and thin grey contour lines have an interval of $200 \mathrm{~m}$. 


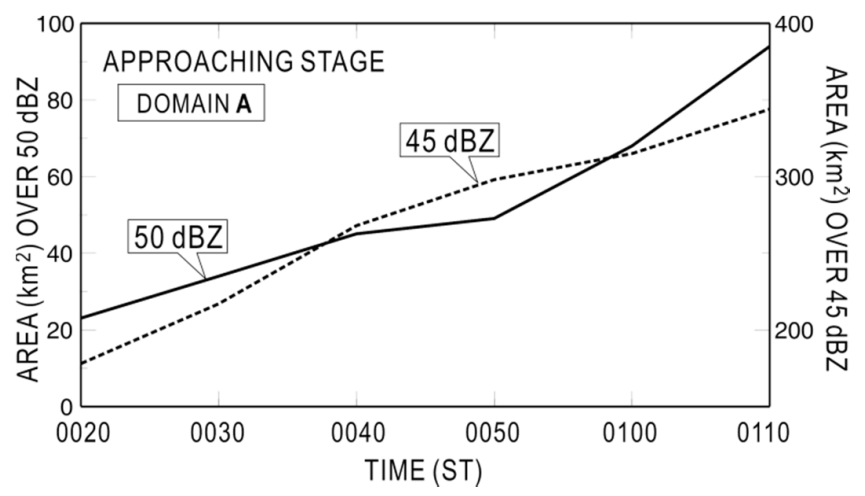

Fig. 5. Temporal variations in the horizontal area of simulated reflectivity greater than $45 \mathrm{dBZ}$ (broken line) and $50 \mathrm{dBZ}$ (solid line) at a height of $1919 \mathrm{~m}$ from 0020 to 0110 ST. The analysis region $\mathbf{A}$ is shown in Fig. $4 \mathrm{~d}$ by a rectangle.

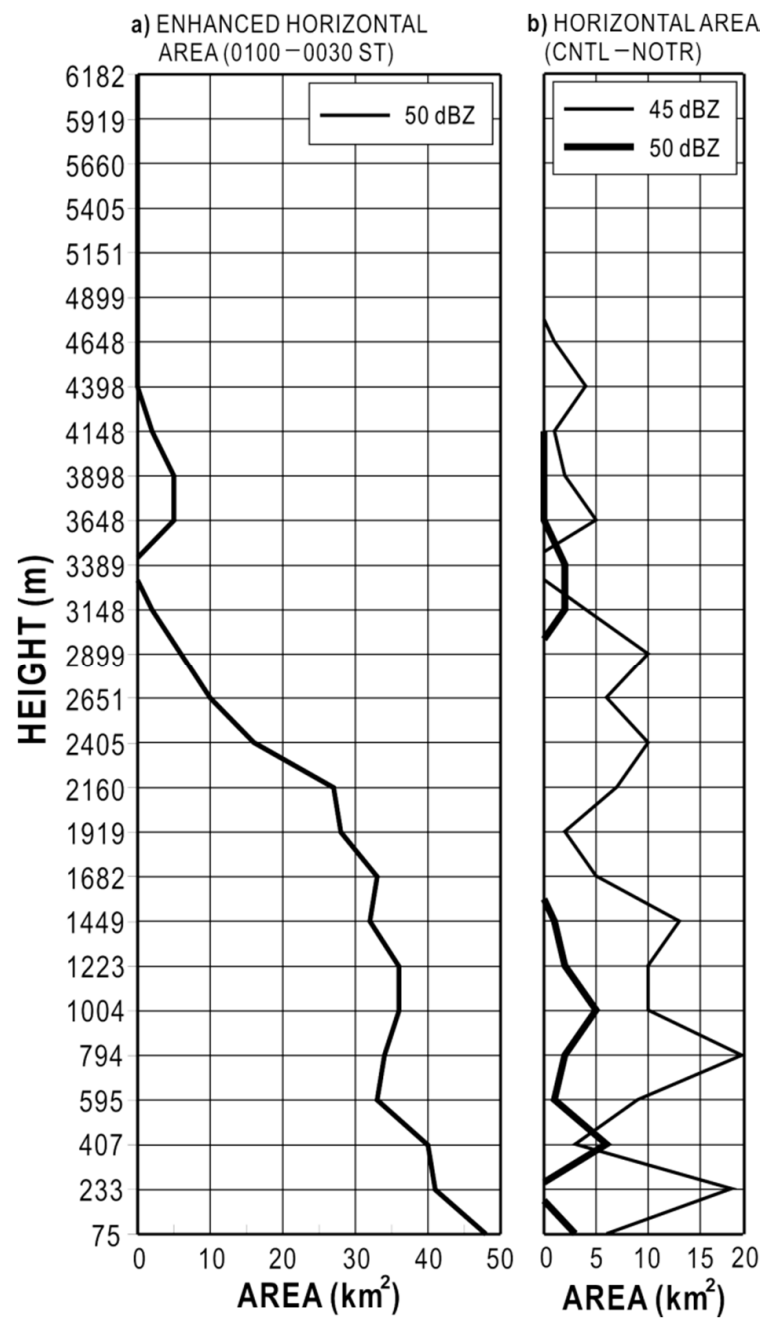

Fig. 6. Vertical profiles of the expanded horizontal area during the approaching stage. (a) Enhanced horizontal area of reflectivity greater than $50 \mathrm{dBZ}$ from 0030 to $0100 \mathrm{ST}$. (b) Differences in horizontal area of reflectivity greater than $45 \mathrm{dBZ}$ (thin line) and $50 \mathrm{dBZ}$ (thick line) between CNTL and NOTR experiments (CNTL minus NOTR) at $0100 \mathrm{ST}$. 


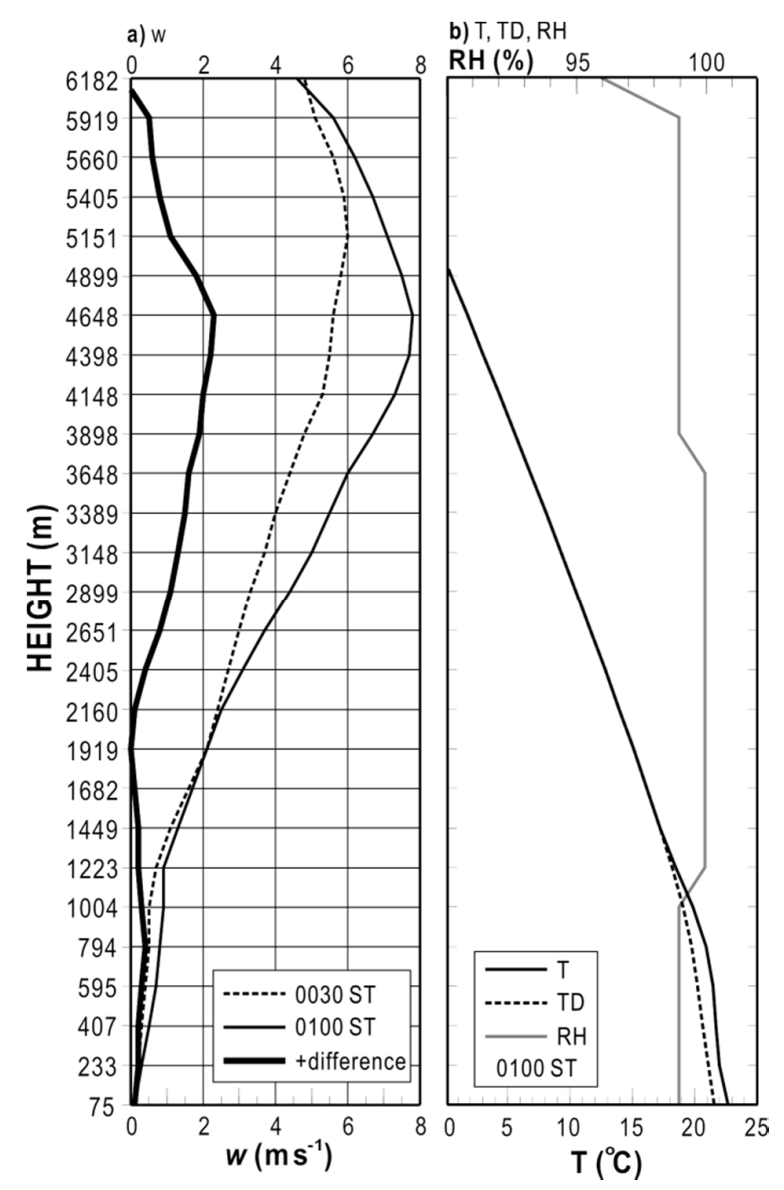

Fig. 7. Vertical profiles of vertical wind $(w)$, temperature (T), dew point temperature (TD), and relative humidity (RH) during the approaching stage. (a) Maximum vertical velocity at $0030 \mathrm{ST}$ (thin broken line), $0100 \mathrm{ST}$ (thin solid line), and the difference between 0030 and 0100 ST (thick solid line: 0100 minus 0030 ST). (b) T (black solid line), TD (broken line), and $\mathrm{RH}$ (grey solid line) at the point of maximum vertical wind at $0100 \mathrm{ST}$. 
a) $0130 \mathrm{ST}$

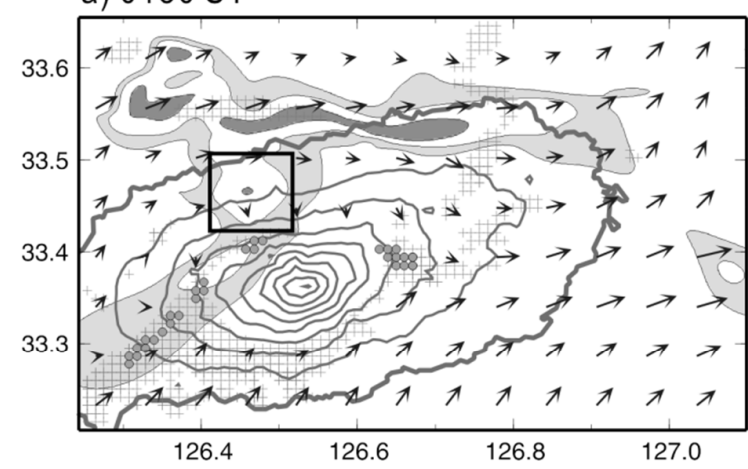

c) $0150 \mathrm{ST}$

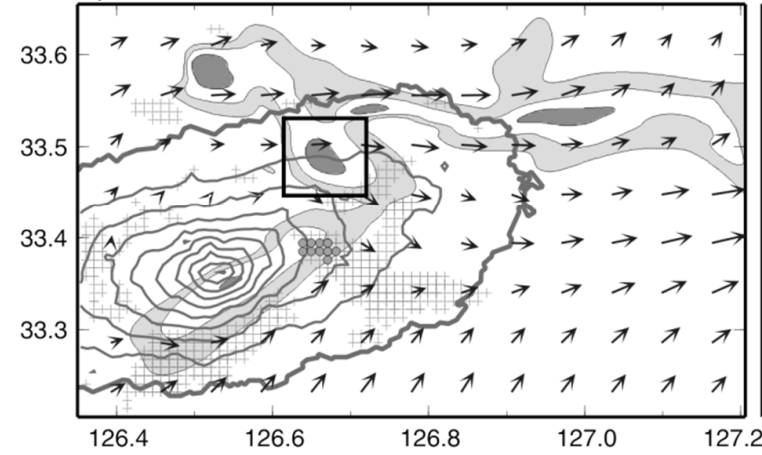

e) $0210 \mathrm{ST}$

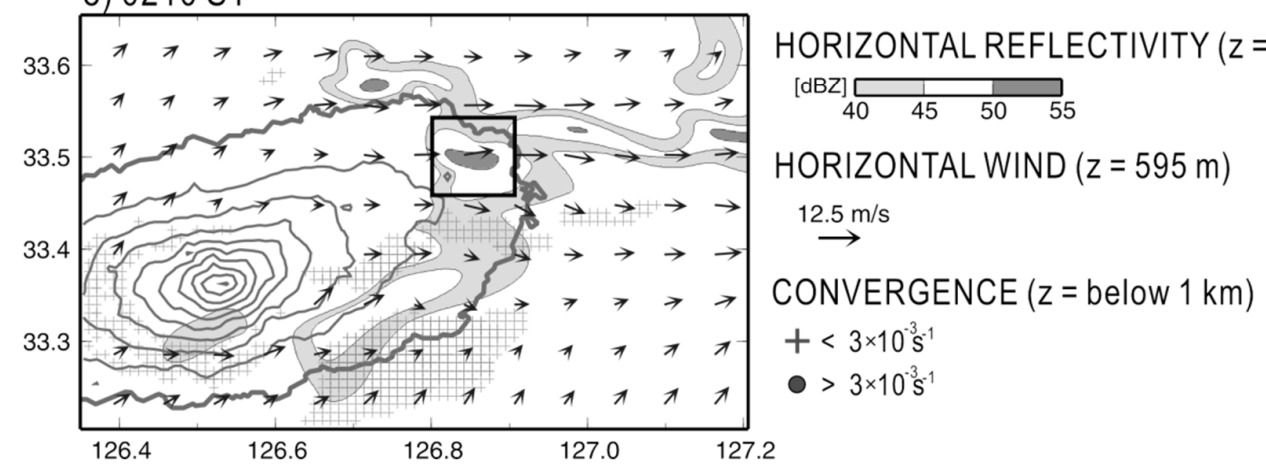

b) $0140 \mathrm{ST}$

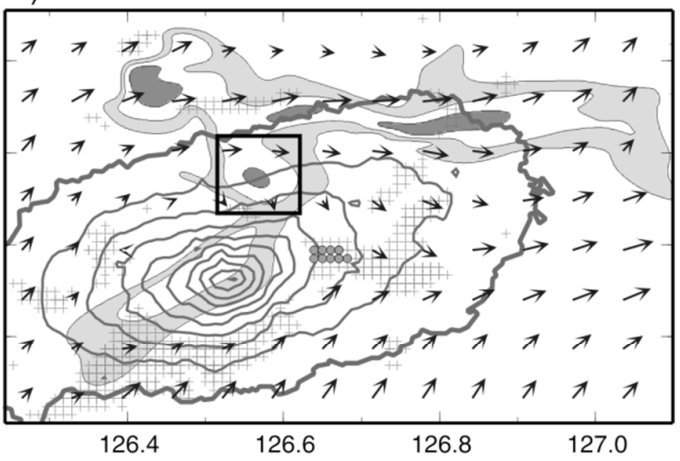

d) $0200 \mathrm{ST}$

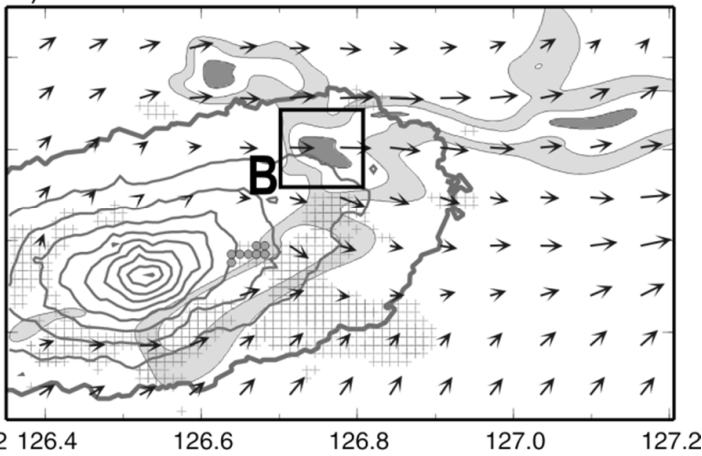

27.2

Fig. 8. Horizontal distributions of wind (vectors) at a height of $595 \mathrm{~m}$, estimated reflectivity (shades) at a height of $1919 \mathrm{~m}$, and convergence (symbols), simulated by the CNTL experiment for (a) $0130 \mathrm{ST}$, (b) $0140 \mathrm{ST}$, (c) $0150 \mathrm{ST}$, (d) $0200 \mathrm{ST}$, and (e) $0210 \mathrm{ST}$. The shaded regions and contours are as in Fig. 4. Rectangles in each panel indicate the regions used for detailed analysis shown in Figs 9, 10, 11, 12, and 13. 


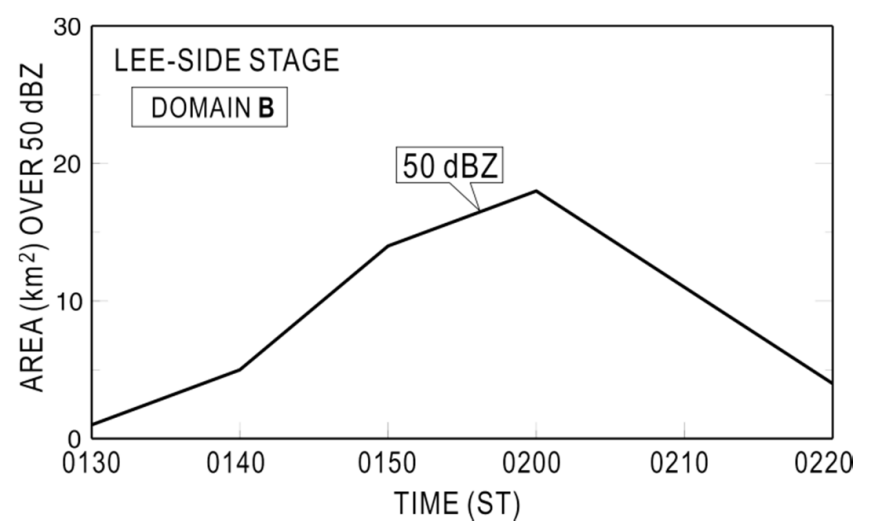

Fig. 9. Temporal variations in the horizontal area of simulated reflectivity greater than $50 \mathrm{dBZ}$ (solid line) at a height of 1919 $\mathrm{m}$ from 0130 to $0220 \mathrm{ST}$. The analysis region $\mathbf{B}$ is shown in Fig. 8 by rectangles.
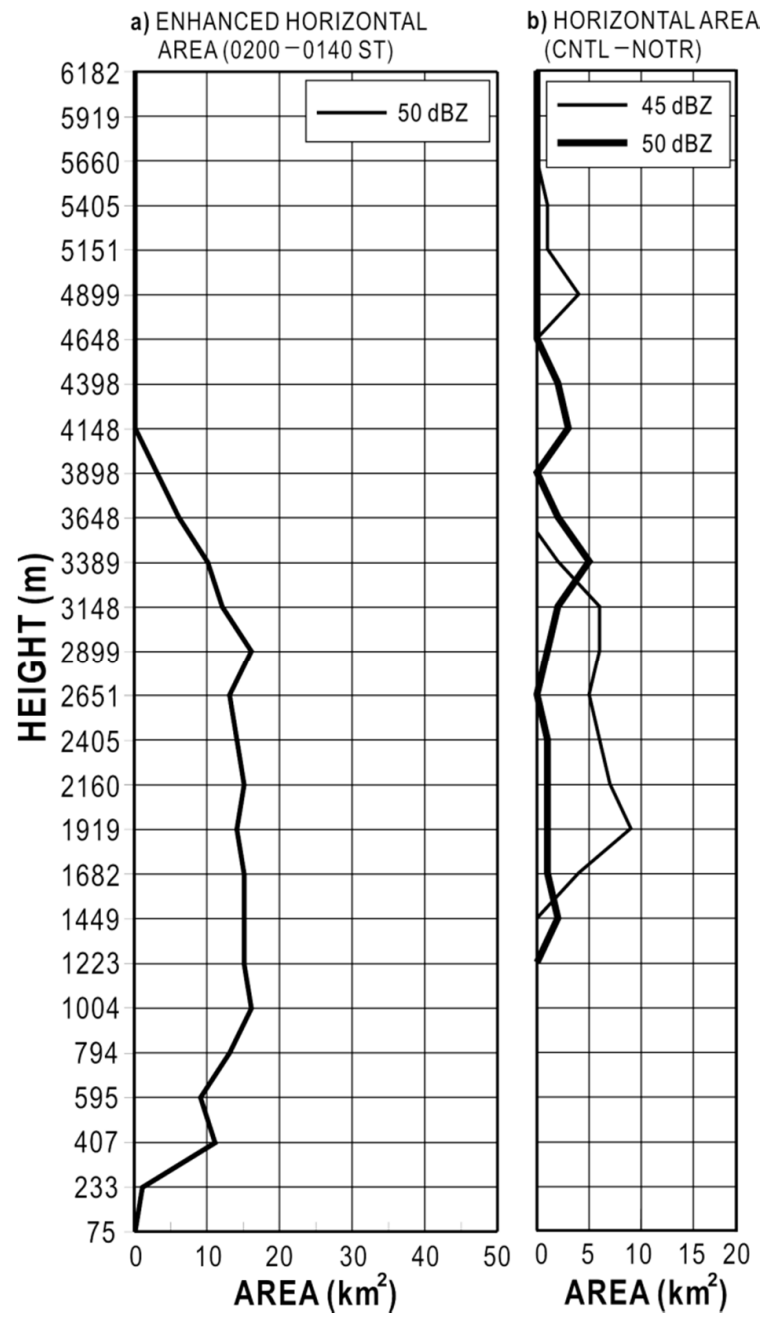

Fig. 10. Vertical profiles of the expanded horizontal area during the lee-side stage. (a) Enhanced horizontal area of reflectivity greater than $50 \mathrm{dBZ}$ from 0140 to $0200 \mathrm{ST}$. (b) Differences in horizontal area of reflectivity greater than $45 \mathrm{dBZ}$ (thin line) and $50 \mathrm{dBZ}$ (thick line) between CNTL and NOTR experiments (CNTL minus NOTR) at 0200 ST. 


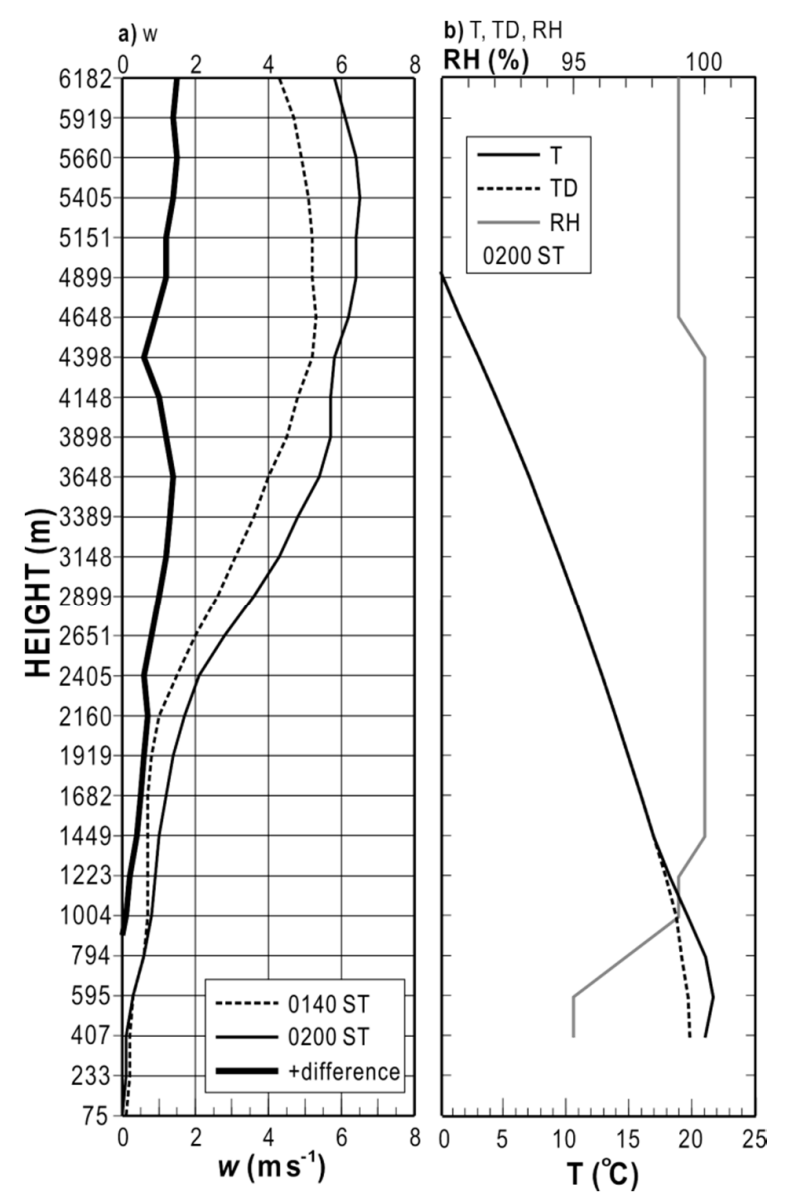

Fig. 11. Vertical profiles of vertical wind $(w)$, temperature (T), dew point temperature (TD), and relative humidity (RH) during the approaching stage. (a) Maximum vertical velocity at 0140 ST (thin broken line), $0200 \mathrm{ST}$ (thin solid line), and the difference between 0140 and 0200 ST (thick solid line: 0200 minus 0140 ST). (b) T (black solid line), TD (broken line), and RH (grey solid line) at the point of maximum vertical wind at $0200 \mathrm{ST}$. 

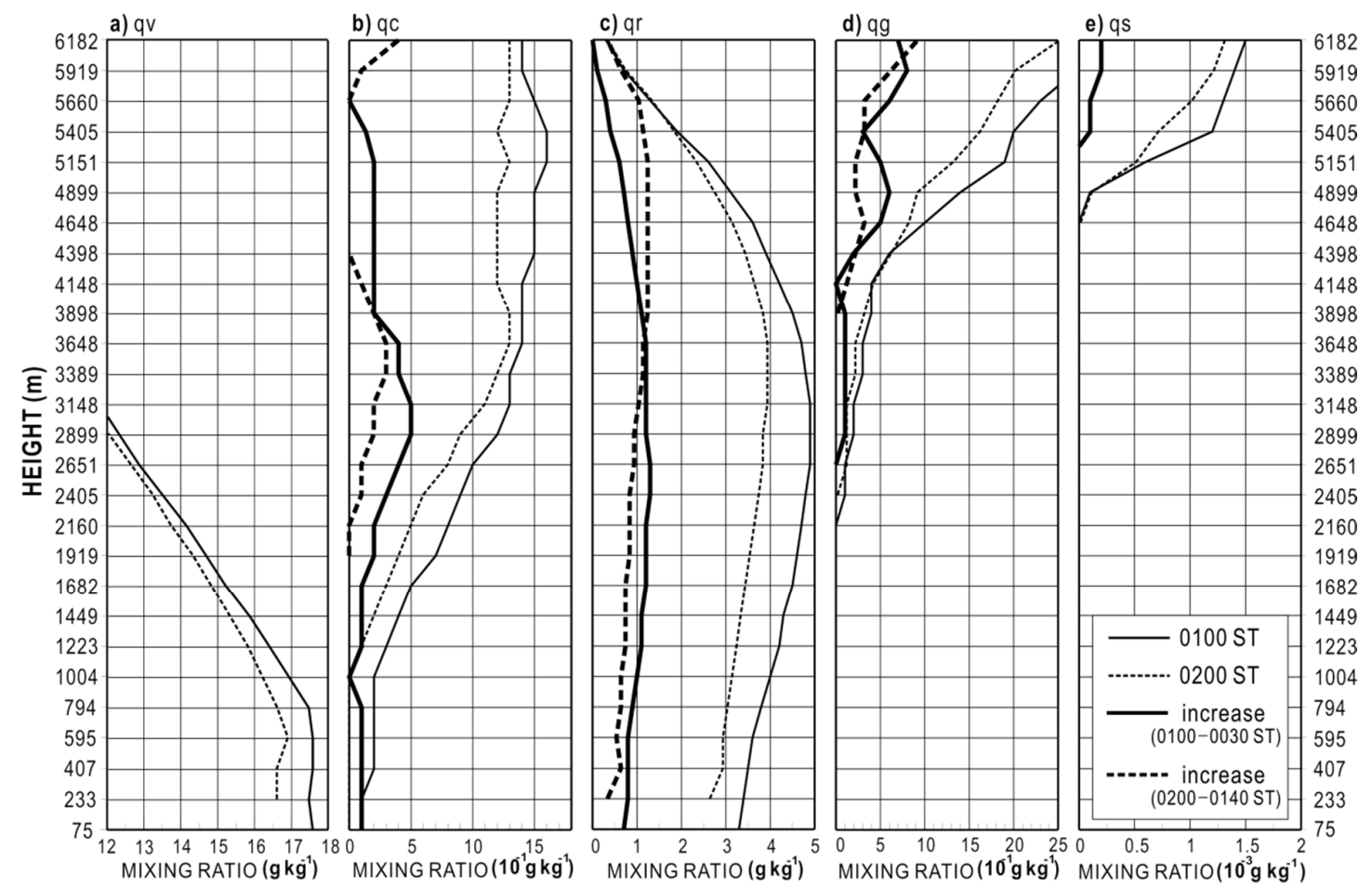

Fig. 12. Vertical profiles of mixing ratios of (a) vapor $\left(q_{v}, \mathrm{~g} \mathrm{~kg}^{-1}\right)$, (b) cloud water $\left(q_{c}, 10^{-1} \mathrm{~g} \mathrm{~kg}^{-1}\right)$, (c) rain water $\left(q_{r}, \mathrm{~g} \mathrm{~kg}^{-1}\right)$, (d) graupel $\left(q_{g}, 10^{-1} \mathrm{~g} \mathrm{~kg}^{-1}\right)$, and (e) snow $\left(q_{s}, 10^{-3} \mathrm{~g} \mathrm{~kg}^{-1}\right)$ at $0100 \mathrm{ST}$ (thin broken line) and $0200 \mathrm{ST}$ (thin solid line). Thick solid lines and thick broken lines in panels $\mathrm{b}-\mathrm{e}$ indicate the increase in each mixing ratio during the approaching and lee-side stages, respectively. 
a) Increase rate of $\mathrm{CN} C R$ $\left(10^{-4} \mathrm{~s}^{-1}\right)$

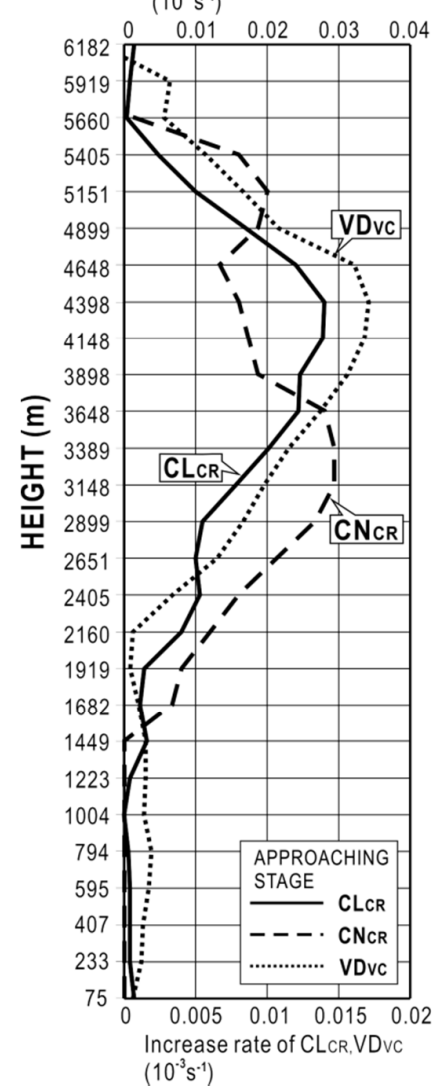

b) Increase rate of $\mathrm{CNCR}$ $\left(10^{-4} \mathrm{~s}^{-1}\right)$
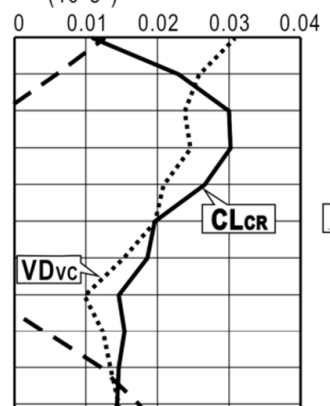

.
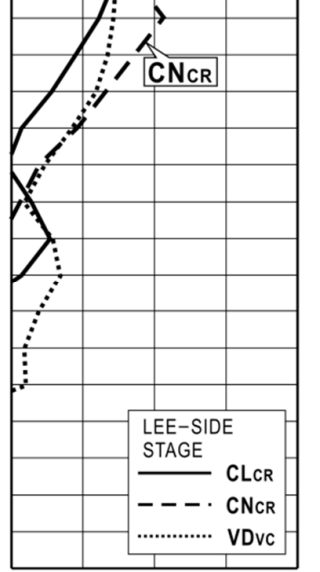

$\begin{array}{cccc}0.005 & 0.01 & 0.015 & 0.02\end{array}$ $\left(10^{-3} \mathrm{~s}^{-1}\right)$
C) Rate of $\operatorname{MLsR}\left(10^{-4} \mathrm{~s}^{-1}\right)$

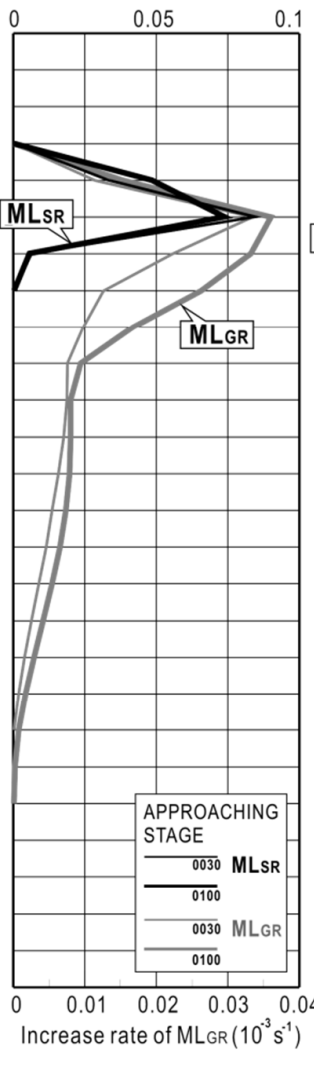

d) Rate of $\operatorname{MLsR}\left(10^{-4} \mathrm{~s}^{-1}\right)$

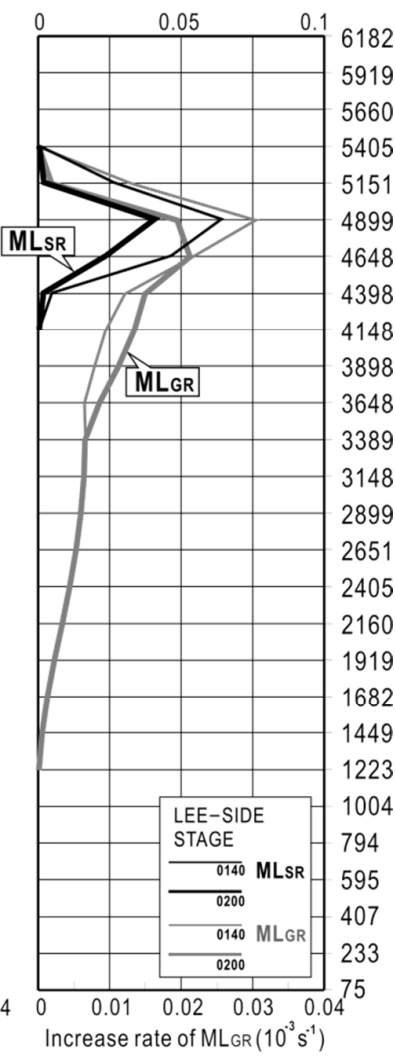

Fig. 13. Vertical profiles of increase rates of microphysical parameters. (a) Increase rate of vapor deposition to cloud water (VDVC, dotted line), collection from cloud water to rain water $\left(\mathrm{CL}_{\mathrm{CR}}\right.$, solid line), and conversion from cloud water to rain water $\left(\mathrm{CN}_{\mathrm{CR}}\right.$, broken line) during the approaching stage. (b) Increase rates of $\mathrm{VD}_{\mathrm{VC}}, \mathrm{CL}_{\mathrm{CR}}$, and $\mathrm{CN}_{\mathrm{CR}}$ during the lee-side stage shown by the dotted, solid, and broken lines, respectively. (c) Maximum melting rates of graupel to rain water ( $\left.\mathrm{ML}_{\mathrm{GR}}\right)$ at $0030 \mathrm{ST}$ (grey thin solid line) and $0100 \mathrm{ST}$ (grey thick solid line), and maximum melting rates of snow to rain water $\left(\mathrm{MLSR}_{\mathrm{SR}}\right.$ ) at $0030 \mathrm{ST}$ (black thin solid line) and $0100 \mathrm{ST}$ (black thick solid line). (d) Maximum rates of ML $\mathrm{GR}_{\text {(grey lines) and }}$ $\mathrm{ML}_{\mathrm{SR}}$ (black line) at $0140 \mathrm{ST}$ (thin lines) and $0200 \mathrm{ST}$ (thick lines). 


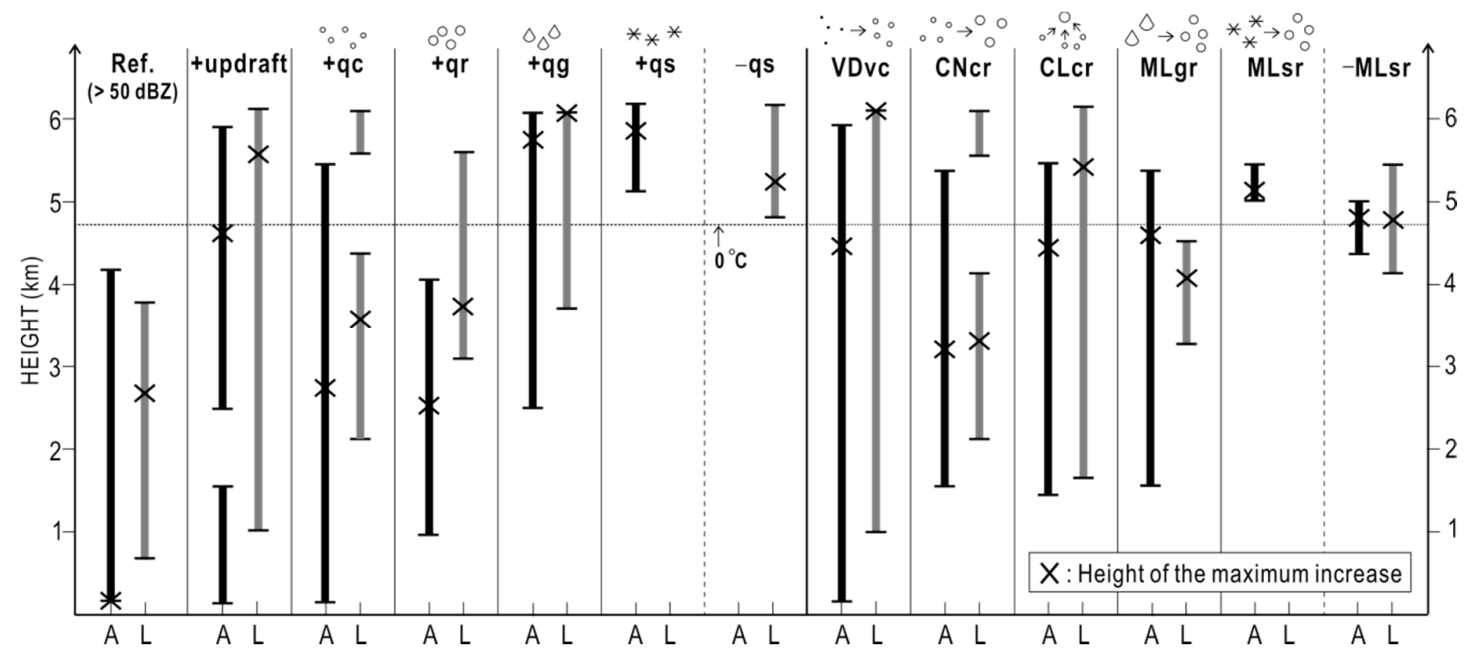

Fig. 14. Height distributions of the increase of the convective region (reflectivity $>50 \mathrm{dBZ}$ ), updraft, mixing ratios of cloud water $\left(q_{c}\right)$, rain water $\left(q_{r}>1 \mathrm{~g} \mathrm{~kg}^{-1}\right)$, graupel $\left(q_{g}\right)$, snow $\left(q_{s}\right)$, and the rates of vapor deposition to rain water (VDVC), conversion from rain water to cloud water $\left(\mathrm{CN}_{\mathrm{CR}}\right)$, collection from cloud water to rain water $\left(\mathrm{CL}_{\mathrm{CR}}\right)$, graupel melting to rain water (MLGR), and snow melting to rain water (MLSR) during the approaching (A, black bars) and lee-side stages ( $\mathbf{L}$, grey bars). The black cross denotes the height of the maximum increase. The height of the $0^{\circ} \mathrm{C}$ level is indicated by the dotted line.
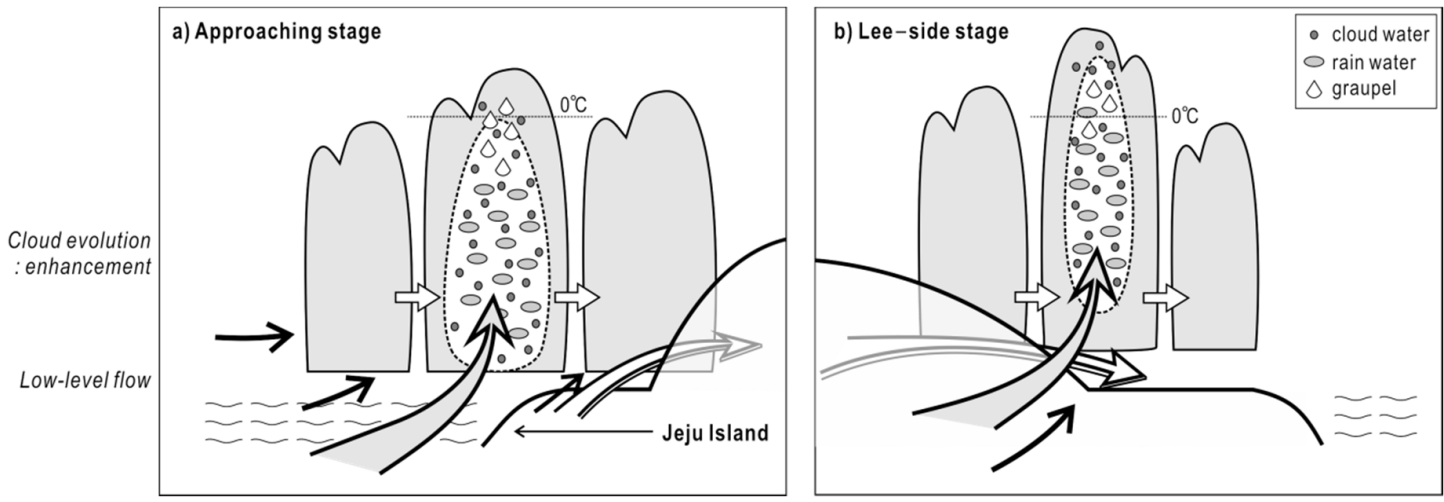

Fig. 15. Schematic illustrations of the enhancements of the microphysical parameters in (a) the approaching stage, and (b) the lee-side stage of the 6 July 2007 precipitation system. Vertical cross-sections of the precipitation area are shown as grey shading. Black arrows indicate the low-level winds. Grey arrows depict local updraft in the vicinity of the terrain. White arrows indicate the terrain-induced circulatory winds at low altitudes. Symbols inside the precipitation area represent the increased hydrometeors. Dark grey circles and light grey ellipses indicate cloud water and rain water, respectively. White diamond indicates graupel. The height of the thick solid line in each panel shows the topography of Jeju Island. 